\title{
The Genetics of Parkinson's Disease and Implications for Clinical Practice
}

\author{
Jacob Oliver Day ${ }^{1}$ and Stephen Mullin ${ }^{1,2, *}$ \\ 1 Faculty of Health, University of Plymouth, Plymouth PL4 8AA, UK; jacob.day@plymouth.ac.uk \\ 2 Department of Clinical and Movement Neurosciences, University College London Institute of Neurology, \\ London WC1N 3BG, UK \\ * Correspondence: stephen.mullin@plymouth.ac.uk
}

check for

updates

Citation: Day, J.O.; Mullin, S. The Genetics of Parkinson's Disease and Implications for Clinical Practice. Genes 2021, 12, 1006. https:/ / doi.org/10.3390/genes12071006

Academic Editor: Allison D. Ebert

Received: 31 May 2021

Accepted: 28 June 2021

Published: 30 June 2021

Publisher's Note: MDPI stays neutral with regard to jurisdictional claims in published maps and institutional affiliations.

Copyright: (c) 2021 by the authors. Licensee MDPI, Basel, Switzerland. This article is an open access article distributed under the terms and conditions of the Creative Commons Attribution (CC BY) license (https:// creativecommons.org/licenses/by/ $4.0 /)$.

\begin{abstract}
The genetic landscape of Parkinson's disease (PD) is characterised by rare high penetrance pathogenic variants causing familial disease, genetic risk factor variants driving PD risk in a significant minority in PD cases and high frequency, low penetrance variants, which contribute a small increase of the risk of developing sporadic PD. This knowledge has the potential to have a major impact in the clinical care of people with PD. We summarise these genetic influences and discuss the implications for therapeutics and clinical trial design.
\end{abstract}

Keywords: Parkinson's disease; genetics; precision medicine; clinical trials; monogenic; polygenic

\section{Introduction}

Parkinson's disease (PD) is a neurodegenerative condition affecting over 6 million people worldwide that is expected to double in prevalence by 2040 [1]. It is characterised by a core set of movement (motor) abnormalities - slowness of movement, muscle rigidity and tremor - as well as a number of non-motor features such as constipation, anxiety and dementia [2]. There is often a prodromal phase of non-motor symptoms which precede motor symptoms by many years [3]. The pathological hallmark of PD is Lewy bodies, which are aggregates of misfolded $\alpha$-synuclein protein (encoded by the SNCA gene) which lead to the loss of midbrain dopamine-producing neurons. However, diagnostic criteria for PD are based on clinical features alone [4,5]. PD can therefore be considered a clinical syndrome with aetiological pathways that converge onto a common final presentation of dopamine loss and clinical Parkinsonism. There are currently no disease-modifying therapies for PD and treatment focusses on dopamine replacement to alleviate symptoms.

The exact cause of PD is unknown. Early twin studies showed only a slight excess of PD in monozygotic compared to dizygotic twins and led to the conclusion that PD was an exclusively acquired condition [6]. However, the discovery of a familial form of PD due to a single gene mutation [7] and later twin studies incorporating a longitudinal design $[8,9]$ have led to the current paradigm of PD as a complex disease with both genetic and environmental contributions [10]. Meta-analysis suggests that the presence of a family history of Parkinson's confers a 3-4× increase in PD risk, implying a significant effect of shared genetic and environmental factors to sporadic PD risk [11].

Age is known to be the greatest risk factor for developing PD [12]. The age-related decline in midbrain dopamine-producing neurons may reach a threshold below which clinical symptoms emerge and an individual's total number of dopaminergic neurons may therefore contribute to the risk and age of onset of PD [13]. A number of environmental exposures have also been associated with PD in observational studies including head trauma, dairy consumption and pesticide exposure [14]. Cigarette smoking and caffeine consumption have been associated with reduced risk of PD, although the biological mechanisms for this remain unclear $[15,16]$. 
Genetic variation is estimated to contribute approximately 25\% to the overall risk of developing PD $[9,17,18]$. The genetic variants related to PD vary in terms of frequency and risk of PD (Figure 1). On the one hand, there are a number of rare variants in single genes that are sufficient to cause disease (i.e., are pathogenic). These monogenic causes of PD were predominantly identified through linkage analysis of affected families. Examples of such genes include SNCA, PARK7 and PRKN. On the other hand, genome wide association studies (GWAS) have identified large numbers of common genetic variants that individually contribute a small amount to the risk of developing PD. In the middle of this spectrum lie variants that are uncommon (but not rare) and exert an intermediate risk, such as GBA and LRRK2 variants.

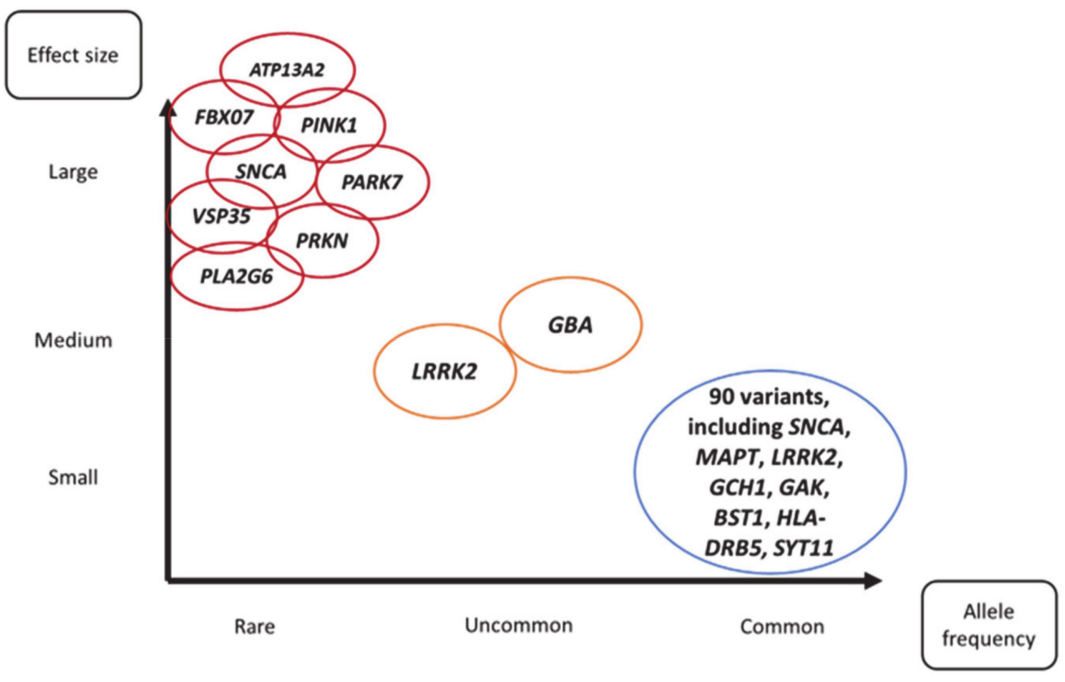

Figure 1. Summary of genetic variants in Parkinson's disease grouped according to allele frequency and associated risk of Parkinson's disease.

Genetics provides one way in which PD can be subdivided. Different subgroups may have separate aetiologies, treatments and prognosis [19]. Common stratification factors for PD include age of onset (early- vs late-onset PD, typically with a cut-off of 50 years of age), the presence or absence of family history (familial vs sporadic PD) and the presence of pathogenic variants (monogenic vs idiopathic PD). Truly monogenic forms of PD are very rare and may not represent the same disease processes that occur in idiopathic PD. For instance, PRKN, PINK1 and PARK7 are all genomic regulators of mitochondrial function [20]. This is important to consider as the majority of laboratory models have focussed on pathways that were identified by monogenic causes of PD [21]. Encouragingly, some of the common variants identified in GWAS also implicate genes that cause monogenic PD [21]. For instance, common variants at the SNCA loci exert the largest contribution to PD risk in GWAS and rare SNCA variants are a cause of monogenic PD, supporting the existing $\alpha$-synuclein centric model of PD [18]. Conversely the MAPT loci encodes tau, aggregates of which are found in a range of neurodegenerative diseases such as Alzheimer's disease, frontotemporal dementia and progressive supranuclear palsy, suggesting the involvement of other pathways in PD pathogenesis [18,22].

An understanding of the genetic factors influencing a disease process can have major impacts on clinical care. Firstly, it can identify causative genes and highlight biological pathways important to pathogenesis. This in turn can allow the development of therapeutics which target those biological pathways. Secondly, it can allow diverse presentations of disease to be accurately subdivided into groups of shared genetic causes. This is essential for 'precision medicine', where management strategies are focussed on an individual's specific disease subtype. Finally, greater knowledge of the effect of genetic variants on the risk, onset and progression of disease means the implications and prognosis can be discussed frankly with individuals, who are then empowered to make educated decisions. 
This review will first summarise the monogenic and polygenic variants associated with PD and then discuss the clinical implications of this knowledge. We shall also draw parallels with diabetes where appropriate to highlight how this knowledge may shape and influence disease management.

\section{Monogenic Parkinson's Disease}

A range of loci and genes have been associated with PD phenotypes in a Mendelian fashion and were originally designated a 'PARK' locus with the number representing the chronological order of discovery. However, multiple PARK loci can refer to the same gene (e.g., PARK1 and PARK4 both refer to SNCA) and some early PARK loci are no longer thought to be disease-causing (e.g., PARK5). Current recommendations are to use gene names in preference to numbered loci [23], although it is important to be aware of this previous nomenclature and the alternative gene names are listed in Table 1 for clarity.

Table 1. Summary of monogenic variants associated with Parkinson's disease.

\begin{tabular}{|c|c|c|c|c|c|c|}
\hline & $\begin{array}{c}\text { Gene (HGNC } \\
\text { Approved Name) }\end{array}$ & $\begin{array}{l}\text { Alternative } \\
\text { Gene Names }\end{array}$ & Inheritance & Pathogenicity & PD Phenotype & Function \\
\hline \multirow{16}{*}{$\begin{array}{l}\text { High } \\
\text { penetrance }\end{array}$} & $S N C A$ & $\begin{array}{c}\text { PARK1, } \\
\text { PARK4, NCAP }\end{array}$ & $\mathrm{AD}$ & Pathogenic & Early-onset & $\begin{array}{c}\text { Uncertain (encodes } \\
\alpha \text {-synuclein) }\end{array}$ \\
\hline & VPS35 & $\begin{array}{l}\text { PARK17, } \\
\text { MEM3 }\end{array}$ & $\mathrm{AD}$ & Pathogenic & Typical & $\begin{array}{l}\text { Retromer and } \\
\text { endosomal } \\
\text { trafficking }\end{array}$ \\
\hline & PINK1 & PARK 6 & AR & Pathogenic & Early-onset & \multirow{3}{*}{ Mitochondrial } \\
\hline & PARK7 & $D J-1$ & AR & Pathogenic & Early-onset & \\
\hline & PRKN & $\begin{array}{l}\text { PARK2, } \\
\text { PARKIN }\end{array}$ & AR & Pathogenic & Early-onset & \\
\hline & PLA2G6 & $\begin{array}{l}\text { PARK14, } \\
\text { IPLA2 }\end{array}$ & AR & Pathogenic & Early-onset, atypical & Cell membrane \\
\hline & ATP13A2 & PARK9 & AR & Pathogenic & Early-onset, atypical & Lysosomal \\
\hline & FBXO7 & $\begin{array}{l}\text { PARK15, } \\
\text { FBX7 }\end{array}$ & AR & Pathogenic & Early-onset, atypical & Mitochondrial \\
\hline & POLG & $\begin{array}{l}\text { POLG1, } \\
\text { POLGA }\end{array}$ & $\mathrm{AD}$ & Pathogenic & Early-onset, atypical & $\begin{array}{c}\text { Mitochondrial } \\
\text { DNA maintenance }\end{array}$ \\
\hline & DNAJC6 & PARK19, DJC6 & AR & $\begin{array}{c}\text { Likely } \\
\text { pathogenic }\end{array}$ & Early-onset & \multirow{4}{*}{$\begin{array}{l}\text { Synaptic vesicle } \\
\text { formation and } \\
\text { trafficking }\end{array}$} \\
\hline & DNAJC13 & $\begin{array}{l}\text { PARK21, } \\
\text { RME8 }\end{array}$ & $\mathrm{AD}$ & $\begin{array}{l}\text { Conflicting } \\
\text { reports }\end{array}$ & Typical & \\
\hline & TMEM230 & C20ORF30 & $\mathrm{AD}$ & $\begin{array}{l}\text { Conflicting } \\
\text { reports }\end{array}$ & Typical & \\
\hline & SYNJ1 & PARK20 & AR & Pathogenic & Early-onset, atypical & \\
\hline & VPS13C & PARK23 & AR & Pathogenic & Early-onset & Mitochondrial \\
\hline & $\mathrm{CHCHD2}$ & - & $\mathrm{AD}$ & Pathogenic & Typical & Uncertain \\
\hline & DCTN1 & - & $\mathrm{AD}$ & Pathogenic & Atypical & Microtubule \\
\hline \multirow[t]{2}{*}{$\begin{array}{l}\text { Variable } \\
\text { penetrance }\end{array}$} & $L R R K 2$ & $\begin{array}{c}\text { PARK8, } \\
D A R D A R I N\end{array}$ & $\mathrm{AD}$ & Pathogenic & Typical & $\begin{array}{l}\text { Lysosomal, } \\
\text { mitochondrial, } \\
\text { microtubule }\end{array}$ \\
\hline & $G B A$ & GBA1 & $\mathrm{AD}$ & Pathogenic & Typical & Lysosomal \\
\hline \multirow{5}{*}{$\begin{array}{l}\text { Associated } \\
\text { with PD but } \\
\text { unlikely to } \\
\text { be } \\
\text { pathogenic }\end{array}$} & HTRA2 & - & $\mathrm{AD}$ & $\begin{array}{l}\text { Uncertain/likely } \\
\text { benign }\end{array}$ & $y$ & Mitochondrial \\
\hline & UCHL1 & PARK 5 & $\mathrm{AD}$ & $\begin{array}{l}\text { Uncertain/likely } \\
\text { benign }\end{array}$ & $y$ & $\begin{array}{l}\text { Ubiquitin- } \\
\text { proteasome }\end{array}$ \\
\hline & GIGYF2 & PARK11 & $\mathrm{AD}$ & $\begin{array}{l}\text { Uncertain/likely } \\
\text { benign }\end{array}$ & $y$ & Uncertain \\
\hline & EIF4G1 & - & $\mathrm{AD}$ & Benign & - & mRNA translation \\
\hline & LRP10 & LRP9 & $\mathrm{AD}^{1}$ & Uncertain & - & Uncertain \\
\hline
\end{tabular}

${ }^{1} \mathrm{AD}=$ autosomal dominant, $\mathrm{AR}=$ autosomal recessive, $\mathrm{HNGC}=$ HUGO Gene Nomenclature Committee. 
Variants with high penetrance are very rare whereas those with variable penetrance are more common worldwide, particularly in specific populations. Table 1 summarises these genes, including those historically associated with PD pedigrees in which subsequent conflicting reports and lack of segregation mean the evidence for pathogenicity is low.

\subsection{Single Genes with High Penetrance}

\subsubsection{SNCA}

The first monogenic cause of PD was discovered in a large Italian family with an autosomal dominant pattern of PD presenting with typical clinical features but early onset (median age 46 years). Linkage studies identified an area of chromosome $4 \mathrm{q}$ that segregated with the disease [24]. Candidate gene sequencing of this region subsequently demonstrated a missense variant (c.209G >A) in the $\alpha$-synuclein gene (SNCA) which causes an amino acid substitution (p.A53T) [7]. The same missense variant was found in unrelated Greek pedigrees. Subsequent studies of familial and sporadic PD cohorts suggest it is an extremely a rare cause of PD overall $[25,26]$. Other missense SNCA variants have since been discovered including p.A30P [27], p.E46K [28] and p.G51D [29]. Duplications and triplications of SNCA can also cause PD with evidence for a 'dosage effect', where greater expression of $\alpha$-synuclein leads to more severe clinical features [30,31]. However, pathogenic SNCA variants only account for a tiny proportion of PD cases [32-34].

$\alpha$-synuclein is highly expressed in the brain and localises predominantly to presynaptic terminals of neurons. The discovery that $\alpha$-synuclein is the major component of Lewy bodies identified a link between the genetic and pathological features of PD [35]. A range of laboratory and animal studies have established that $\alpha$-synuclein can form abnormal aggregates which are neurotoxic [36-38]. $\alpha$-synuclein aggregates are able to spread within the central nervous system with the fibril form being particularly toxic. Different clinical features are observed depending on the form and location of abnormal $\alpha$-synuclein aggregates [39]. This aggregation process is accelerated by SNCA pathogenic variants or by an increase in intracellular alpha synuclein concentration disrupting proteasome function and exacerbating oxidative stress $[40,41]$.

Despite the rarity of pathogenic SNCA variants, the relevance of $\alpha$-synuclein to both monogenic and idiopathic forms of PD has been established by the presence of Lewy bodies, the altered expression of SNCA in neurons of people with idiopathic PD [42] and the SNCA loci identified in GWAS studies of idiopathic PD (see Section 3.). A number of overlapping functions for $\alpha$-synuclein have been proposed with interactions demonstrated with other monogenic PD gene products and involvement in multiple pathways including synaptic vesicle function, lysosomal function, mitochondrial function and inflammation [43]. Therefore the biological pathways of $\alpha$-synuclein aggregation have become the central hypothesis for the molecular processes causing PD.

\subsubsection{VPS35}

Independent exome sequencing studies in 2011 identified a missense variant in the VPS35 gene (p.D620N) of Swiss [44] and Austrian [45] families with an autosomal dominant pattern of PD that cosegregrated within the family and was not present in healthy controls. VPS35 encodes a component of the multimeric retromer complex which mediates trafficking of endosomes. It appears to be important in neuronal transport to dendrites [46] and neuronal cells from humans with the p.D620N variant show disrupted endosomal transport and abnormal accumulation of $\alpha$-synuclein and reactive oxygen species $[47,48]$. Although pathogenic variants in VPS35 are particularly rare, comprising only $0.2 \%$ of European patients with suspected autosomal dominant PD, patients manifest typical PD symptoms with a good response to L-DOPA $[49,50]$. It is reasonable to consider that the gene function, particularly with its association with $\alpha$-synuclein and mitochondrial function, is also implicated in sporadic PD. 


\subsubsection{PRKN/ PARK7/ PINK1}

These genes will be considered together as their protein products are linked to mitochondrial function and biallelic variants all cause autosomal recessive forms of PD. Between 1998 and 2004, studies of families, often consanguineous, affected by early-onset forms of PD with a suspected autosomal recessive inheritance pattern identified biallelic loss of function variants in PRKN (previously called Parkin) [51], PARK7 (previously called DJ-1) [52] and PINK-1 [53]. PRKN encodes Parkin which is a ubiquitin ligase involved in the proteasomal degradation system [54] and also has a role in the maintenance of mitochondrial structure and DNA integrity [55]. PARK7 encodes the DJ-1 protein (or Parkinson disease protein 7) whose specific function is unclear but has been shown to interact with a number of proteins including tau [56], Parkin and PINK1. The product of PINK1, PTEN-induced kinase 1, is a mitochondrially associated kinase that may have an anti-inflammatory role in animal models [57]. Parkin, DJ-1 and PINK1 form a ubiquitin ligase complex whose function is impaired by pathogenic variants [58]. Taken together, the evidence suggests that Parkin, DJ-1 and PINK1 interact within the ubiquitin-proteasome system and have a role in the maintenance of mitochondrial structure. Autopsy studies have shown variable results with respect to Lewy body pathology in these genetic forms of PD. In particular, initial studies demonstrated a lack of Lewy bodies in patients with biallelic PRKN mutations, questioning its relevance to sporadic PD [59-61]. However, subsequent case reports have identified Lewy bodies in homozygous and heterozygous cases of PRKN-PD [62,63].

\subsubsection{Others}

A number of other genes have been implicated in monogenic PD (see Table 1) but either result in a complex phenotype with significant features in addition to Parkinsonism or have less robust evidence for pathogenicity.

ATP13A2 biallelic variants result in adolescent-onset PD with dementia and hallucinations [64]. The protein is involved in lysosomal function [65]. Biallelic variants in the $\mathrm{FBXO7}$ gene have been associated with an early-onset form of PD with pyramidal signs [66-68] and FBXO7 interacts with PINK1 to enable its degradation [69]. Biallelic variants in the phospholipase-encoding PLA2G6 gene were originally described in neurodegeneration with brain iron accumulation but can also cause autosomal recessive $\mathrm{PD}$ with or without cognitive, pyramidal and dystonic features [70-72]. DNAJC6 and SYNJ1 encode interacting proteins involved in synaptic vesicle recycling and result in early-onset autosomal recessive forms of PD [73,74]. DNAJC13 and TMEM230 also have a role in synaptic vesicle processing, but variants were discovered in the same affected PD pedigree and their pathogenicity remains uncertain [75].

Some genes have only been reported in single pedigrees plus isolated cases (e.g., TMEM230 variants $[75,76])$ or have conflicting presence in healthy controls (e.g., UHCL1, HTRA2 [77]). These could represent variants with reduced penetrance or simply erroneous associations with disease.

\subsection{Single Genes with Variable Penetrance}

LRRK2 and GBA have been associated with familial PD. GBA in particular does not tend to demonstrate a Mendelian (i.e., autosomal recessive or dominant pattern) of inheritance. They can either be considered as genetic 'risk factors', where the presence of certain variants confers an increased risk developing PD, or as autosomal dominant pathogenic variants with incomplete penetrance. The distinction is somewhat arbitrary, particularly when different variants are considered, as some display high penetrance and could be considered monogenic causes of PD.

\subsubsection{LRRK2}

Heterozygous missense LRRK2 variants were originally identified in families with autosomal dominant patterns of PD inheritance $[78,79]$. Subsequent work has identified 
the c.6055G >A variant (p.G2019S) as the most common pathogenic variant worldwide. It is particularly common in Ashkenazi Jewish and North African Berber populations with prevalence rates, respectively, as high as $26 \%$ and $41 \%$ in some cohorts. The risk of PD by aged 80 years in carriers of the p.G2019S variant is estimated to be $25-74 \%$ [80-82]. A number of other pathogenic LRRK2 variants have been described. Some have been described through linkage studies in kindreds with Parkinson disease with an autosomal dominant pattern of inheritance, whilst other appear to exert marginal increases in PD, characterised by genetic case control data $[83,84]$. This hints at significant heterogeneity of PD risk associated with individual $L R R K 2$ variants, although our understanding of this is certainly not as developed as in the case of GBA.

Both environmental (e.g., cigarette smoking, non-steroidal anti-inflammatories) and genetic modifiers have been proposed as factors to explain this incomplete penetrance [85-87]. Penetrance of LRRK2-PD varies between Arab Berbers and Norwegians, whereas age of onset of idiopathic PD does not, suggesting disparate genetic and environmental modifiers in LRRK2-PD penetrance [88]. Conversely, some studies have suggested a lower penetrance amongst Ashkenazi Jewish p.G2019S subjects, although this difference in penetrance may reflect varying degrees of ascertainment bias (i.e., where carriers were identified on this basis of being blood relatives of an index case with PD and may carry genetic cofactors that increase PD risk) [81]. The PD polygenic risk score modifies LRRK2-PD penetrance and 1 significant individual locus has been identified that modifies penetrance (within the CORO1C gene) [89]. The risk of PD varies according to the specific $L R R K 2$ variants and certain variants, such as p.R1398H, appear to exert a protective effect [90].

The clinical phenotype of LRRK2-PD is broadly similar to that of idiopathic PD with a good response to L-DOPA and a median age of onset of 57 years. However, there is contradictory evidence as to the specific phenotype of $L R R K 2-P D$. Some studies suggest that p.G2019S LRRK2 variants may have higher rates of motor complications $[83,91]$. One large study suggests a more benign clinical course with a tremor predominant phenotype [82], although other studies do not replicate this finding [81]. The identification of LRRK2 missense variants in $\sim 1 \%$ of sporadic PD and LRRK2 loci in GWAS, suggests that LRRK2 has an important role in idiopathic as well as LRRK2-PD.

LRRK2 encodes the leucine-rich repeat kinase 2 protein which has both kinase and GTPase domains. Its physiological role is thought to include autophagy, mitochondrial function and microtubule stability [92]. Pathogenic variants lead to increased kinase domain activity, raising the tantalising possibility of pharmacological inhibition as a possible therapeutic strategy [93,94]. Moreover, LRRK2 kinase activity is enhanced in post-mortem brain tissue of people with idiopathic PD who lack LRRK2 variants [95]. Despite animal models suggesting off target effects of LRRK2 inhibition [96,97], the apparent benign presence of heterozygous loss of function $L R R K 2$ variants in humans is reassuring that partial reduction in LRRK2 function is safe [98,99].

\subsubsection{GBA}

Biallelic (i.e., homozygous or compound heterozygous] variants in the GBA gene can lead to Gaucher disease, a lysosomal storage disorder caused by reduced activity of the $G B A$-encoded enzyme glucocerebrosidase (GCase). Its relevance to PD was first considered when patients with Gaucher disease were noted to develop disproportionate levels of Parkinsonian features [100]. The observation of high rates of PD in the families of those with Gaucher disease suggested that heterozygous GBA variants cause PD independently [101]. Case-control studies across various populations confirmed an increased risk of PD in those with $G B A$ variants [102].

Unhelpfully, two nomenclatures which include or omit a 39 amino acid leader of the GBA gene exist. Here we refer to the more commonly used historical classification, with the newer classification (which complies with HGNC guidelines) in brackets.

The range of $G B A$ variants identified (to date over 200 Gaucher causing $G B A$ variants have been documented $[103,104])$ complicates estimation of PD risk. High quality prospec- 
tive data amongst those with a diagnosis of Gaucher disease suggest that by 80 years the penetrance of PD is approximately $10 \%$ [105]. As with LRRK2, it is likely that ascertainment bias has inflated risk estimates of PD penetrance in at least some cohorts $[106,107]$. Overall genetic case control data suggests that eleven [predominantly missense] individual GBA variants increase PD risk [108]. p.N370S (p.N409S) and p.L444P (p.L483P) are the most common worldwide, with the p.N370S (p.N409S) variant particularly seen in Ashkenazi Jewish populations [109]. Respectively, they increase the risk of PD by $\times 4$ and $\times 12$. A number of meta-analyses have also estimated cumulative risks associated with all GBA mutations, but the significant heterogeneity of penetrance of individual $G B A$ variants makes these estimates of limited usefulness [102,108]. Stratification of PD risk of GBA variants based on the Gaucher disease phenotype [namely the presence or absence of neurological features associated with them] provides a more relevant estimate of risk. Aggregated 'mild' variants increase PD risk by $\times 3$ compared to the general population, whilst 'severe' variants (associated with neurological GD features) increase this risk by $\times 15$ [110]. p.E326K (p.E365K) and p.T369M (p.T408M), found commonly in European populations, double PD risk compared to the general population, but do not cause Gaucher disease [108,111-113]. Collectively $10-15 \%$ of European PD patients carry a PD associated GBA variant, making it numerically the most significant PD genetic risk factor by some distance [33].

Similarly to $L R R K 2$, both environmental and genetic cofactors are postulated to explain the reduced penetrance of $G B A$ variants. A recent GWAS of individuals with $G B A$ variants with and without PD showed that the PD risk loci implicating SNCA and CTSB were significantly associated with GBA-PD [114]. CTSB encodes a lysosomal protease which may interact with GCase.

The closely related GBAP pseudogene has important implications for the study of $G B A$, as certain sequencing techniques are required to identify specific $G B A$ variants. Depending on the techniques used, studies may only report on specifically targeted variants and miss other variants present in the GBA gene [115]. By using a PCR enrichment step, both Illumina based sequencing by synthesis [116] and long read sequencing using the Oxford Nanopore has been shown to reliably screen the entire GBA gene. The latter has been reliably able to phase variants, which is a distinct advantage, because quite a number of pathogenic GBA variants are in fact complex haplotypes derived from reciprocal translocations with the GBA pseudogene [117].

The clinical phenotype of GBA-PD is similar to that of idiopathic PD, although there is robust evidence that $G B A$ variants in those with PD confer an earlier age of onset, higher rates of dementia and faster progression of motor symptoms [99,118-121]. 'Severe' GBA variants are associated with more exaggerated clinical features [110]. This is also the case when variant pathogenicity is predicted with in silico methods [122]. Importantly, both p.E326K (p.E365K) and p.T369M(p.T408M), are associated with an increased risk of cognitive impairment and more rapid disease progression $[123,124]$, in spite of the relatively small increase in PD risk associated with them.

In contrast to many of the other genes implicated in monogenic PD, the biological role of GBA is well understood. GCase is a lysosomal hydrolase that breaks down glucosylceramide into ceramide and glucose. GBA variants have differential effects on both the enzymatic activity of GCase and its trafficking within cells [125]. This identifies both enzyme action and cellular trafficking of GCase as potential therapeutic targets. Blood, cerebrospinal fluid (CSF) and brain GCase activity levels have been shown to be lower in idiopathic PD as well as GBA-PD, suggesting that novel GBA targeted therapies may also be beneficial in idiopathic PD [126-128].

\subsubsection{Heterozygous PRKN as a PD Genetic Risk Factor}

Although bialleic PRKN variants are an established cause of PD, considerable controversy surrounds the effect on PD risk of heterozygous PRKN variants. Heterozygous $P R K N$ variants are common finding amongst those with PD. One large study found that some $1.2 \%$ of early onset/familial PD cases carry a PRKN variant [33]. The same study 
found that PRKN carriers had an age at onset some 12 years lower than PD cases without other genetic risk factors. There is, however, conflicting data regarding the effect they exert on PD risk. A number of small studies suggest PRKN variants do increase PD risk however no association has been found in other studies [129] including in a recent analysis of some 2807 patients and 3627 controls [130-132]. It may be that only a portion of PRKN variants, and in particular those with a truncating effect on protein function, confer an effect of PD risk. This may explain the discontinuity of results seen.

\section{Sporadic Parkinson's Disease}

In contrast to studies of familial PD that initially identified monogenic associations through studies of affected pedigrees, the genetics of sporadic PD has primarily advanced through case-control GWAS of common genetic variants. GWAS are powerful techniques to identify genetic loci that have a small but additive effect on traits of interest and can identify biological pathways relevant to that trait. The combined effect of multiple common genetic variants (typically defined as a minor allele frequency of greater than $5 \%$ ) contributes to the risk of developing a common disease, such as sporadic PD. Whereas twin studies show greatest PD heritability when onset is below 50 years (capturing the highly penetrant but rare monogenic causes), GWAS heritability is greatest in those with PD onset over 50 years, demonstrating that common variants have the greatest genetic contribution to the risk of late-onset PD [9,17].

Table 2 summarises GWAS of idiopathic PD performed to date according to the National Human Genome Research Institute GWAS Catalog [133]. The majority of idiopathic PD-related GWAS have focused on variants associated with the risk of developing PD. Only a minority have interrogated possible associations with other traits such as age of PD onset, progression of disease or response to medications. Furthermore, most studies have used European cohorts thus limiting the applicability of results to worldwide populations. Table 2 demonstrates that the larger the GWAS cohort, the greater the number of significant loci identified. This has also been shown for other common continuous traits such as height and body mass index [134] and also other binary disease states such as type 2 diabetes [135]. The information from these GWAS can be utilised in two main ways: firstly, the biological functions captured by associated variants can identify underlying disease mechanisms; secondly, the combined information from all associated variants can produce a 'polygenic risk score' to quantify an individual's genetic risk of developing a trait.

GWAS have identified new genes relevant to the risk of developing PD. However, the actual functional effect indicated by trait-associated variants can be challenging to determine. Moreover, significant variants tag a genomic region with which that variant is in linkage disequilibrium and most common variants are found in non-coding regions of the genome. Therefore, post-GWAS analyses are critical in assigning biological function to GWAS variants. Examples of post-GWAS analyses include pathway analysis (where groups of variants are analysed together to determine the relevance of sets of gene to the trait] and expression quantitative trait loci (eQTL) analysis (which identifies variants associated with the expression of genes and so identifies a regulatory element) [136]. In PD, robust associations from multiple GWAS and subsequent post-GWAS analyses have been identified for SNCA, RAB29, MAPT, BST1, GAK, LRRK2 and HLA-DRB5 amongst others [18,137]. GAK has a role in synaptic endocytosis and so links this pathway in sporadic PD to the rare forms of DNAJC6 and SYNJ1 monogenic PD. Intriguingly, some of these genes harbour common variants that increase risk to sporadic disease as well as rare variants that cause monogenic PD, indicating shared biological pathways (e.g., SNCA).

A polygenic risk score (PRS) allows the combined effect of GWAS variants to be quantified in an individual. A PRS will therefore depend on the variants included and will be specific to the cohort ethnicity and to the trait under consideration. Using the variants from Nalls et al. [18] there is approximately 4 times greater odds of PD in the highest PRS quartile compared with the lowest quartile. Additionally, the PD risk PRS has consistently been shown to correlate with age of onset in multiple ethnicities, despite the fact that PD 
age of onset GWAS have found very few significant variants [138-141]. A study using an Asian cohort demonstrated that an ethnicity-specific PRS enhances performance [142]. Despite this consistent association of PRS with disease state and age of onset, addition of PRS to clinical decision tools only has a limited impact [141,143]. A recent study used a novel approach to assess association between the PRS of genes within pre-specified functional pathways and the risk of PD and identified 46 significantly associated pathways, including 6 that did not involve any of the previously identified GWAS loci [144].

Despite this progress in identifying many common variants associated with PD risk, GWAS can still only account for $16-36 \%$ of PD heritability [18]. In the future, we anticipate that larger cohorts incorporating different ethnicities will identify more lower risk variants and that assessing different PD-related traits will further contribute to the polygenic architecture of PD. However it is important to emphasize that GWAS is of limited use for the identification of some genetic risk factors, for example GBA. Because it relies upon arrays of directly genotyped variants and then imputes other variants by linkage disequilibrium, important disease associated variants can be missed. In fact, GWAS was only able to identify the GBA locus using a candidate gene approach [145]. It may be that other such genetic risk factors contribute to PD risk but remain undetected by current GWAS analyses. Expanding our understanding of these genetic contributors to idiopathic PD risk is likely to require forensic examination of sequencing data, a time consuming, expensive and highly complex process [146].

Table 2. Summary of idiopathic Parkinson's disease GWA studies included in NHGRI-EBI Catalog of human genome-wide association studies.

\begin{tabular}{|c|c|c|c|c|c|}
\hline Study & Year & $\begin{array}{c}\text { Cohort Size (Cases: } \\
\text { Controls) }\end{array}$ & Trait & Ethnicity & $\begin{array}{c}\text { Number of } \\
\text { Genome-Wide } \\
\text { Significant Loci }\end{array}$ \\
\hline Fung et al. [147] & 2006 & $267: 270$ & PD & European & 0 \\
\hline Pankratz et al. [148] & 2009 & $857: 867$ & Familial PD & European & 0 \\
\hline Latourelle et al. [149] & 2009 & $1604: 440$ & PD age of onset & European & 0 \\
\hline Satake et al. [150] & 2009 & 1921:18274 & PD & East Asian & 4 \\
\hline Simón-Sánchez et al. [151] & 2009 & 5074:8551 & PD & European & 3 \\
\hline Edwards et al. [152] & 2010 & 1752:1745 & PD & European & 2 \\
\hline Hamza et al. [153] & 2010 & 2000:1986 & PD & European & 4 \\
\hline Saad et al. [154] & 2011 & 4271:9048 & PD & European & 2 \\
\hline Simón-Sánchez et al. [155] & 2011 & $772: 2024$ & PD & European & 0 \\
\hline Liu et al. [156] & 2011 & 2050:1836 & PD & European & 0 \\
\hline Spencer et al. [157] & 2011 & $2744: 7159$ & PD & European & 3 \\
\hline Nalls et al. [158] & 2011 & 12386:21026 & PD & European & 11 \\
\hline Do et al. [159] & 2011 & $3426: 29624$ & PD & European & 8 \\
\hline Chung et al. [160] & 2012 & 443:0 & $\begin{array}{c}\text { PD motor and } \\
\text { cognitive outcomes }\end{array}$ & European & 0 \\
\hline Hernandez et al. [161] & 2012 & $387: 496$ & Early-onset PD & Finnish & 0 \\
\hline Pankratz et al. [145] & 2012 & $7976: 6350$ & PD & European & 5 \\
\hline Davis et al. [162] & 2013 & $31: 767$ & PD & European & 0 \\
\hline Hill-Burns et al. [163] & 2014 & 4235:2782 & $\begin{array}{l}\text { Familial and sporadic } \\
\text { PD }\end{array}$ & European & 4 \\
\hline Nalls et al. [137] & 2014 & 19061:100833 & PD & European & 24 \\
\hline Hu et al. [164] & 2016 & $250: 250$ & PD & East Asian & 0 \\
\hline
\end{tabular}


Table 2. Cont.

\begin{tabular}{|c|c|c|c|c|c|}
\hline Study & Year & $\begin{array}{c}\text { Cohort Size (Cases: } \\
\text { Controls) }\end{array}$ & Trait & Ethnicity & $\begin{array}{c}\text { Number of } \\
\text { Genome-Wide } \\
\text { Significant Loci }\end{array}$ \\
\hline Hill-Burns et al. [165] & 2016 & 1168:0 & $\begin{array}{l}\text { Familial PD age of } \\
\text { onset }\end{array}$ & European & 2 \\
\hline Siitonen et al. [166] & 2017 & $403: 1650$ & Early-onset PD & Finnish & 13 \\
\hline Foo et al. [167] & 2017 & 5904:30831 & PD & East Asian & 3 \\
\hline Chang et al. [168] & 2017 & 26035:403190 & PD & European & 41 \\
\hline Wallen et al. [169] & 2018 & $2676: 0$ & PD age of onset & European & 1 \\
\hline Blauwendraat et al. [170] & 2019 & 28568:0 & PD age of onset & European & 2 \\
\hline Bandres-Ciga et al. [171] & 2019 & 4783:3066 & $\begin{array}{c}\text { PD and PD age of } \\
\text { onset }\end{array}$ & European & 5 \\
\hline Nalls et al. [18] & 2019 & $\begin{array}{c}\text { 37688(plus } 18618 \text { proxy } \\
\text { cases): } 1417791\end{array}$ & PD & European & 90 \\
\hline Ryu et al. [172] & 2020 & 741:0 & $\begin{array}{l}\text { Motor complications } \\
\text { of PD }\end{array}$ & East Asian & 1 \\
\hline Cha et al. [173] & 2020 & 200:0 & $\begin{array}{l}\text { PD motor response to } \\
\text { zonisamide }\end{array}$ & East Asian & 1 \\
\hline Tan et al. [174] & 2020 & 2755:0 & PD progression & European & 1 \\
\hline Foo et al. [142] & 2020 & 65257:1896188 & PD & $\begin{array}{l}\text { East Asian } \\
\text { and } \\
\text { European }\end{array}$ & 10 \\
\hline
\end{tabular}

\section{Therapeutics}

\subsection{Disease-Modifying Agents for PD}

A disease-modifying agent in PD would be one that slows or stops the processes leading to neuronal loss. Where there is a single gene abnormality that greatly increases the risk of $\mathrm{PD}$, strategies targeted at that variant and its biological consequences are appealing. This is particularly the case for GBA and LRRK2 because they are so much more common than other monogenic causes of PD. However, any successful agents may only be effective in that group of patients who harbour a variant and so applicability to idiopathic PD is not guaranteed. We summarise some of the therapies whose targets have been informed by PD genetics that are currently under evaluation for the disease-modification for PD.

\subsubsection{GBA}

While Gaucher disease can be managed with enzyme replacement, GCase does not cross the blood brain barrier so this is not a viable option in PD [175]. Instead, small molecules that are able to cross the blood-brain barrier and enhance the action of GCase are being explored. Currently two agents are registered in phase II clinical trials. The first is ambroxol, which is a small molecule chaperone of GCase that is already in clinical use as a cough linctus medicine. It is well-tolerated and has been shown to increase levels of GCase protein in the CSF of 17 individuals with $\mathrm{PD}$ (8 with GBA variants) [176]. A blinded placebocontrolled trial is underway to assess whether ambroxol is able to improve cognition in PD dementia [NCT02914366] and is expected to complete in December 2021 [177], whilst a further phase III clinical trial evaluating the outcome in PD itself is planned. The second is venglustat, a small molecule inhibitor of glucosylceramide synthase which catalyses production of the substrate for GCase and has shown efficacy in mouse GBA and SNCA models of neurodegeneration [178]. Disappointingly, a phase II trial showed that although a reduction in glucosylceramide was demonstrated in CSF, no clinical difference was demonstrated comparted to controls (in fact, a non-significant deterioration was seen in the intervention arm) [179]. A third approach is the use of gene therapy, whereby a viral vector 
injected directly into CSF is used to restore the wildtype GBA sequence. The limitation of such approaches to date has been the inability to achieve sufficient transfection in the target organ. A phase I study is currently recruiting to evaluate PR001A, a viral vector-based therapy to deliver GBA which rescues GCase activity and reduces $\alpha$-synuclein levels in cell and mouse models [180], in patients with moderate to severe PD and GBA variants (NCT04127578). Preliminary results evaluation are expected in mid-2021.

\subsubsection{LRRK2}

As already mentioned, inhibition of LRRK2 is an attractive therapeutic strategy as pathogenic variants cause overactivation of the kinase domain and loss of function variants in humans have no associated disease phenotypes. Moreover, a wide range of small molecule kinase inhibitors have been developed for use in other diseases [181]. Two molecules have emerged from pre-clinical testing that appear to offer suitable pharmacokinetic profiles and have completed phase I studies (NCT03710707, NCT04056689). The molecule DNL151 has recently been shown to be well tolerated in healthy volunteers and people with PD and demonstrated inhibition of LRRK2 function [182]. An alternative strategy targeting LRRK2 overactivity is using antisense oligonucleotides to target mRNA for degradation. Intrathecal administration may also avoid off-target effects in other organs. A preclinical study in mice showed that centrally delivered LRRK2 antisense oligonucleotide reduced $\alpha$-synuclein aggregates and increased dopaminergic neurons, without effects on the kidneys or lungs [183]. A phase I study of a LRRK2 antisense oligonucleotide (BIIB094) in people with PD is registered and due to complete in 2023 [NCT03976349].

\subsubsection{SNCA}

As well as these studies specifically targeting GBA and $L R R K 2$ cellular processes, there are a range of compounds that target $\alpha$-synuclein which could be beneficial in those with SNCA variants but also, importantly, those with idiopathic PD. Immunotherapy approaches attempt to remove toxic forms of $\alpha$-synuclein using antibodies which are either passively administered or actively stimulated via vaccination. Two $\alpha$-synuclein antibodies, prazinezumab and cinpanemab have progressed to phase II clinical trials (NCT03100149 and NCT03318523). The $\alpha$-synuclein peptide mimic, PD01A, which stimulates an immune response has been shown to be well tolerated in a phase I study of people with PD [184]. A phase II trial is intended but not yet registered. As well as immunotherapy techniques, molecules that directly inhibit aggregation of $\alpha$-synuclein are being evaluated. Phase II studies are registered for the molecules ANVS-401 (NCT04524351) and ENT-01 (NCT03781791). However, nilotinib, which is used in chronic myeloid leukaemia and has been shown to accelerate $\alpha$-synuclein degradation, showed no efficacy [185].

\subsubsection{Mitochondria}

Genetic and environmental evidence have implicated mitochondrial dysfunction in PD and strategies that enhance mitophagy are likely to be beneficial to all forms of PD. Three repurposed oral medications that improve mitochondrial function are being assessed in phase II trials of idiopathic PD - ursodeoxycholic acid (NCT03840005 [186] ), terazosin(NCT03905811) and nicotinamide (NCT03568968). In addition, the novel agent EPI-589 is being assessed in a phase II trial of both idiopathic PD and genetic forms of PD that alter mitochondrial function (NCT02462603).

\subsection{Pharmacogenomics}

Genetics can allow for selection of treatments for genetically stratified disease subgroups. Both PD and diabetes manifest clinical features when the action of a chemical messenger (dopamine in PD and insulin in diabetes) is reduced. Diabetes therefore serves as a useful analogy for how our current knowledge of PD genetics may one day be used to optimise clinical care and management [187]. 
A major success in the field of diabetes genetics has been the recognition that certain monogenic causes of diabetes are best treated by specific treatments. In particular, the discovery that patients with activating variants in the ABCC8 and KCNJ11 [188] genes respond better to sulfonylurea medications than to insulin allowed individuals with these variants to stop insulin injections [189]. Maturity onset diabetes of the young (MODY) is another monogenic form of diabetes which presents in early adulthood and typically can be managed with oral hypoglycaemic medications. Genetic stratification of MODY subtypes has allowed for homogenous cohort studies and evidence that certain medications are preferable in specific gene variants $[190,191]$. Indeed, in the case of MODY due to GCK mutations, it has been possible to determine that no treatment at all is necessary [192]. Finally, the polygenic type 1 diabetes risk score can be used as one domain to help differentiate type 1 from type 2 diabetes and therefore determine whether an individual is likely to require insulin treatment [193].

In $\mathrm{PD}$, choice of treatment depends on a range of factors including patient preference and risk of side effects. However, prediction of side-effects is difficult and some can have extremely serious consequences for an individual (e.g., impulse control disorders). The ability to accurately predict serious side effects, as well as likely response, would be of great benefit to individual patients. A large number of common variants in genes related to dopamine action and metabolism have been associated with medication effectiveness and side effects in PD. These include dopamine receptor genes (DRD1, DRD2, DRD3, $D R D 4)$, dopamine transporter gene (SLC6A3) and the catechol-O-methyltransferase gene (COMT) [194]. However, many of these association studies have been small in number and focus on a subset of candidate genes. Moreover, some have shown contradictory findings $[195,196]$.

More recent studies have evaluated genome-wide common variants in an hypothesisfree method which have the potential to identify novel genetic modifiers of medication response [173]. Using genotype data in addition to clinical parameters has been shown to significantly improve the ability to predict the occurrence of impulse control disorders in people with a recent diagnosis of PD and a mean follow up of 2.2 years (AUC increased from 0.64 to 0.76 ). Indeed the heritability of impulse control disorder was estimated at $57 \%$, suggesting a predominant genetic component [197]. In contrast, in a retrospective study of people with PD looking at the time to develop L-DOPA induced motor complications, addition of genotype to clinical data did not lead to any improvement in the model [198].

A recent systematic review of treatment in monogenic forms of PD highlights the challenges in drawing conclusions about the best treatment for each subtype [199]. Data were available for 2226 patients, with the majority being those with PRKN (1002) or LRRK2 (820) variants. Overall 420 variants in 6 genes (SNCA, LRRK2, VPS35, PRKN, PINK1, PARK7) were identified. There were very high rates of missing data for doses and specific adverse effects. Overall the treatment efficacies and side-effects appear to be broadly similar to that of idiopathic PD but conclusions regarding rare variants and non-L-DOPA therapies should be treated with caution. Several groups have demonstrated poorer outcomes of deep brain stimulation surgery in those with Parkinson's who carrying a GBA variant, with some suggesting that in these cases the benefits of surgery do not outweigh the risk and hence, other less invasive advanced PD therapies should be selected in these cases $[200,201]$.

\section{Selecting Appropriate PD Cohorts for Clinical Trials}

Interventional clinical trial arms should be matched so that they only differ in terms of exposure to the intervention. Any difference, including genetic variation, between the arms can lead to false negative or false positive results. We know that some forms of monogenic PD progress at different rates (e.g., GBA-PD tends to have faster motor and cognitive progression then idiopathic PD). In addition, a higher PD risk PRS has been associated with faster motor progression as assessed by Hoehn \& Yahr and UPDRS-III scores, which are commonly used as endpoints in clinical trials [202]. Indeed, in predictions 
of PD progression using machine learning models, genetic variation was a better predictor than imaging or CSF biomarkers [203].

Not accounting for genetic variation has the potential to inadvertently lead to mismatched clinical trial arms. A study of simulated clinical trial scenarios using genetic data from 5851 people with PD estimated that the average PRS varied by up $22 \%$ in trials containing up to 1000 individuals. Further analysis of virtual cohorts showed that for trials with 50 individuals and an intervention that reduced the MDS-UPDRS by 0.5/year, over one third would report false negative results as a result of genetically unbalanced arms [204]. Although these findings could be partially mitigated by larger sample sizes and longer follow ups, these strategies have implications in terms of cost and practicality. In principle, balancing clinical trial arms by genetics could lead to better evaluation of any intervention, although this would require baseline genotyping of all participants and appropriate consenting.

Recruitment of specific genetic risk factors for PD (for example only individuals with LRRK2 p.G2019S PD) could enable more genetically stratified cohorts. This can also allow for targeted therapies to be studied as currently being recruited for LRRK2- and GBA-targeted compounds. However, we know that the PRS and other genetic factors still modify progression in these groups [114,205]. Conversely, as our understanding of the genetics underlying PD risk and progression evolves, balancing trial arms may become increasingly difficult, requiring an unattainably large pool of potential participants to draw from.

As well as balancing trial arms, there is potential for using genetics to recruit cohorts that progress faster, either because of monogenic risk or high PRS. Whereas for an individual the knowledge that certain groups progress faster on average may be disconcerting and unhelpful, for a clinical trial cohort this is useful information. Recruiting a cohort of GBA carriers, for instance, could reduce the follow up required for trials to meet their endpoints, thereby reducing cost, minimising participant burden and accelerating drug discovery [206]. Conversely, if indeed LRRK2-PD has a slower rate of progression, a larger trial size would be required.

\section{Prodromal PD}

A major challenge in trials of all neurodegenerative conditions is recruiting individuals at an early stage of disease who have the most to gain from disease-modifying therapies [the so-called 'window of opportunity']. It has been suggested that a combination of clinical features and biomarkers can be utilised to identify people with pre-symptomatic or prodromal disease. PD has a well-established prodromal phase with published research criteria which, since the 2019 update, incorporates PRS and age-related penetrance of certain GBA and LRRK2 variants [3]. This could potentially be utilised to identify those 'at risk' or with early PD who may respond more favourably to disease-modifying therapies. That said, the sensitivity and specificity of attempts to stratify the risk of conversion to PD in at risk populations have to date been disappointing [207-209], with the exception of those carrying LRRK2 variants [210]. This may reflect the high penetrance [and by extension hazard ratio] associated with this genetic risk factor.

A number of longitudinal cohorts have studied the pre-symptomatic features of PD and attempted to identify predictors of conversion to clinical PD, often using a combination of measures [211-213]. Both LRRK2 and GBA carriers have been shown to exhibit prodromal PD features such as hyposmia [209], REM sleep behaviour disorder [214] and dopaminergic loss [215] and/or glial activation on PET imaging. This raises difficult ethical issues for clinical trials that still remain to be overcome. If an intervention is required to be taken for many years, then the safety profile of that intervention must be rigorously assessed. Given the range of penetrance risk and progression of PD even within specific variants, accurate power calculations and recruitment numbers are difficult to ascertain $[216,217]$. 


\section{Concluding Remarks}

Over the last 30 years it has been recognised that genetics contributes approximately $25 \%$ to the risk of developing PD. Characterisation of the exact genes involved and their function has enabled identification of relevant biological pathways are involved in its pathogenesis. This has been the case for both rare monogenic causes of PD and the more common late-onset polygenic PD. Indeed, there is significant overlap in the genetic risk factors suggesting shared disease mechanisms. With this increasing wealth of genetic knowledge, new strategies to assimilate the information and make it available to clinicians, researchers and patients are being created [218-220]. Whereas the treatment implications for different forms of monogenic diabetes have driven genetic testing into clinical practice, this is not yet the case for routine PD care, although examples of this are beginning to emerge [33,221,222]. While it is possible to provide some information to individual patients regarding risk of disease and prognosis, the range of predictions creates uncertainty. Knowledge of genetics has the potential to improve clinical trial design as well as to generate new and optimise existing therapeutic options for people with PD.

Author Contributions: J.O.D. and S.M. wrote the manuscript and were responsible for its review and critique. All authors have read and agreed to the published version of the manuscript.

Funding: J.O.D. is supported by the National Institute for Health Research as an Academic Clinical Fellow. S.M. is supported by the National Institute for Health Research as an Academic Clinical Lecturer.

Institutional Review Board Statement: Not applicable.

Informed Consent Statement: Not applicable.

Data Availability Statement: Data sharing not applicable.

Conflicts of Interest: The authors declare no conflict of interest.

\section{References}

1. GBD 2016 Neurology Collaborators. Global, regional, and national burden of Parkinson's disease, 1990-2016: A systematic analysis for the Global Burden of Disease Study 2016. Lancet Neurol. 2018, 17, 939-953. [CrossRef]

2. Jankovic, J. Parkinson's disease: Clinical features and diagnosis. J. Neurol. Neurosurg. Psychiatry 2008, 79, 368-376. [CrossRef] [PubMed]

3. Heinzel, S.; Berg, D.; Gasser, T.; Chen, H.; Yao, C.; Postuma, R.B.; MDS Task Force on the Definition of Parkinson's Disease. Update of the MDS research criteria for prodromal Parkinson's disease. Mov. Disord. 2019, 34, 1464-1470. [CrossRef] [PubMed]

4. Hughes, A.J.; Daniel, S.E.; Kilford, L.; Lees, A.J. Accuracy of clinical diagnosis of idiopathic Parkinson's disease: A clinicopathological study of 100 cases. J. Neurol. Neurosurg. Psychiatry 1992, 55, 181-184. [CrossRef]

5. Postuma, R.B.; Berg, D.; Stern, M.; Poewe, W.; Olanow, C.W.; Oertel, W.; Obeso, J.; Marek, K.; Litvan, I.; Lang, A.E.; et al. MDS clinical diagnostic criteria for Parkinson's disease. Mov. Disord. 2015, 30, 1591-1601. [CrossRef]

6. Duvoisin, R.C.; Eldridge, R.; Williams, A.; Nutt, J.; Calne, D. Twin study of Parkinson disease. Neurology 1981, 31, 77-80. [CrossRef]

7. Polymeropoulos, M.H.; Lavedan, C.; Leroy, E.; Ide, S.E.; Dehejia, A.; Dutra, A.; Pike, B.; Root, H.; Rubenstein, J.; Boyer, R.; et al. Mutation in the alpha-synuclein gene identified in families with Parkinson's disease. Science 1997, 276, 2045-2047. [CrossRef]

8. Wirdefeldt, K.; Gatz, M.; Reynolds, C.A.; Prescott, C.A.; Pedersen, N.L. Heritability of Parkinson disease in Swedish twins: A longitudinal study. Neurobiol. Aging 2011, 32, 1923.e1-1923.e8. [CrossRef]

9. Goldman, S.M.; Marek, K.; Ottman, R.; Meng, C.; Comyns, K.; Chan, P.; Ma, J.; Marras, C.; Langston, J.W.; Ross, G.W.; et al. Concordance for Parkinson's disease in twins: A 20-year update. Ann. Neurol. 2019, 85, 600-605. [CrossRef]

10. Blauwendraat, C.; Nalls, M.A.; Singleton, A.B. The genetic architecture of Parkinson's disease. Lancet Neurol. 2020, 19, 170-178. [CrossRef]

11. Noyce, A.J.; Bestwick, J.P.; Silveira-Moriyama, L.; Hawkes, C.H.; Giovannoni, G.; Lees, A.J.; Schrag, A. Meta-analysis of early nonmotor features and risk factors for Parkinson disease. Ann. Neurol. 2012, 72, 893-901. [CrossRef]

12. Pang, S.Y.; Ho, P.W.; Liu, H.F.; Leung, C.T.; Li, L.; Chang, E.E.S.; Ramsden, D.B.; Ho, S.L. The interplay of aging, genetics and environmental factors in the pathogenesis of Parkinson's disease. Transl. Neurodegener. 2019, 8, 23. [CrossRef]

13. von Linstow, C.U.; DeLano-Taylor, M.; Kordower, J.H.; Brundin, P. Does Developmental Variability in the Number of Midbrain Dopamine Neurons Affect Individual Risk for Sporadic Parkinson's Disease? J. Parkinsons Dis. 2020, 10, 405-411. [CrossRef]

14. Ascherio, A.; Schwarzschild, M.A. The epidemiology of Parkinson's disease: Risk factors and prevention. Lancet Neurol. 2016, 15, 1257-1272. [CrossRef] 
15. Breckenridge, C.B.; Berry, C.; Chang, E.T.; Sielken, R.L.; Mandel, J.S. Association between Parkinson's Disease and Cigarette Smoking, Rural Living, Well-Water Consumption, Farming and Pesticide Use: Systematic Review and Meta-Analysis. PLoS ONE 2016, 11, e0151841. [CrossRef]

16. Qi, H.; Li, S. Dose-response meta-analysis on coffee, tea and caffeine consumption with risk of Parkinson's disease. Geriatr. Gerontol. Int. 2014, 14, 430-439. [CrossRef]

17. Keller, M.F.; Saad, M.; Bras, J.; Bettella, F.; Nicolaou, N.; Simón-Sánchez, J.; Mittag, F.; Büchel, F.; Sharma, M.; Gibbs, J.R.; et al. Using genome-wide complex trait analysis to quantify 'missing heritability' in Parkinson's disease. Hum. Mol. Genet. 2012, 21, 4996-5009. [CrossRef]

18. Nalls, M.A.; Blauwendraat, C.; Vallerga, C.L.; Heilbron, K.; Bandres-Ciga, S.; Chang, D.; Tan, M.; Kia, D.A.; Noyce, A.J.; Xue, A.; et al. Identification of novel risk loci, causal insights, and heritable risk for Parkinson's disease: A meta-analysis of genome-wide association studies. Lancet Neurol. 2019, 18, 1091-1102. [CrossRef]

19. Marras, C.; Lang, A. Parkinson's disease subtypes: Lost in translation? J. Neurol. Neurosurg. Psychiatry 2013, 84, 409-415. [CrossRef]

20. Correia Guedes, L.; Mestre, T.; Outeiro, T.F.; Ferreira, J.J. Are genetic and idiopathic forms of Parkinson's disease the same disease? J. Neurochem. 2020, 152, 515-522. [CrossRef]

21. Shadrina, M.I.; Slominsky, P.A.; Limborska, S.A. Molecular mechanisms of pathogenesis of Parkinson's disease. Int. Rev. Cell Mol. Biol. 2010, 281, 229-266. [CrossRef]

22. Bouchard, M.; Suchowersky, O. Tauopathies: One disease or many? Can. J. Neurol. Sci. 2011, 38, 547-556. [CrossRef]

23. Marras, C.; Lang, A.; van de Warrenburg, B.P.; Sue, C.M.; Tabrizi, S.J.; Bertram, L.; Mercimek-Mahmutoglu, S.; Ebrahimi-Fakhari, D.; Warner, T.T.; Durr, A.; et al. Nomenclature of genetic movement disorders: Recommendations of the international Parkinson and movement disorder society task force. Mov. Disord. 2016, 31, 436-457. [CrossRef]

24. Polymeropoulos, M.H.; Higgins, J.J.; Golbe, L.I.; Johnson, W.G.; Ide, S.E.; Di Iorio, G.; Sanges, G.; Stenroos, E.S.; Pho, L.T.; Schaffer, A.A.; et al. Mapping of a gene for Parkinson's disease to chromosome 4q21-q23. Science 1996, 274, 1197-1199. [CrossRef]

25. Muñoz, E.; Oliva, R.; Obach, V.; Martí, M.J.; Pastor, P.; Ballesta, F.; Tolosa, E. Identification of Spanish familial Parkinson's disease and screening for the Ala53Thr mutation of the alpha-synuclein gene in early onset patients. Neurosci. Lett. 1997, 235, 57-60. [CrossRef]

26. Vaughan, J.; Durr, A.; Tassin, J.; Bereznai, B.; Gasser, T.; Bonifati, V.; De Michele, G.; Fabrizio, E.; Volpe, G.; Bandmann, O.; et al. The alpha-synuclein Ala53Thr mutation is not a common cause of familial Parkinson's disease: A study of 230 European cases. European Consortium on Genetic Susceptibility in Parkinson's Disease. Ann. Neurol. 1998, 44, 270-273. [CrossRef]

27. Krüger, R.; Kuhn, W.; Müller, T.; Woitalla, D.; Graeber, M.; Kösel, S.; Przuntek, H.; Epplen, J.T.; Schöls, L.; Riess, O. Ala30Pro mutation in the gene encoding alpha-synuclein in Parkinson's disease. Nat. Genet. 1998, 18, 106-108. [CrossRef]

28. Zarranz, J.J.; Alegre, J.; Gómez-Esteban, J.C.; Lezcano, E.; Ros, R.; Ampuero, I.; Vidal, L.; Hoenicka, J.; Rodriguez, O.; Atarés, B.; et al. The new mutation, E46K, of alpha-synuclein causes Parkinson and Lewy body dementia. Ann. Neurol. 2004, 55, 164-173. [CrossRef]

29. Lesage, S.; Anheim, M.; Letournel, F.; Bousset, L.; Honoré, A.; Rozas, N.; Pieri, L.; Madiona, K.; Dürr, A.; Melki, R.; et al. G51D $\alpha$-synuclein mutation causes a novel parkinsonian-pyramidal syndrome. Ann. Neurol. 2013, 73, 459-471. [CrossRef]

30. Singleton, A.B.; Farrer, M.; Johnson, J.; Singleton, A.; Hague, S.; Kachergus, J.; Hulihan, M.; Peuralinna, T.; Dutra, A.; Nussbaum, R.; et al. alpha-Synuclein locus triplication causes Parkinson's disease. Science 2003, 302, 841. [CrossRef]

31. Ross, O.A.; Braithwaite, A.T.; Skipper, L.M.; Kachergus, J.; Hulihan, M.M.; Middleton, F.A.; Nishioka, K.; Fuchs, J.; Gasser, T.; Maraganore, D.M.; et al. Genomic investigation of alpha-synuclein multiplication and parkinsonism. Ann. Neurol. 2008, 63, 743-750. [CrossRef] [PubMed]

32. Benitez, B.A.; Davis, A.A.; Jin, S.C.; Ibanez, L.; Ortega-Cubero, S.; Pastor, P.; Choi, J.; Cooper, B.; Perlmutter, J.S.; Cruchaga, C. Resequencing analysis of five Mendelian genes and the top genes from genome-wide association studies in Parkinson's Disease. Mol. Neurodegener. 2016, 11, 29. [CrossRef] [PubMed]

33. Skrahina, V.; Gaber, H.; Vollstedt, E.J.; Förster, T.M.; Usnich, T.; Curado, F.; Brüggemann, N.; Paul, J.; Bogdanovic, X.; Zülbahar, S.; et al. The Rostock International Parkinson's Disease (ROPAD) Study: Protocol and Initial Findings. Mov. Disord. 2020. [CrossRef]

34. Tan, M.M.X.; Malek, N.; Lawton, M.A.; Hubbard, L.; Pittman, A.M.; Joseph, T.; Hehir, J.; Swallow, D.M.A.; Grosset, K.A.; Marrinan, S.L.; et al. Genetic analysis of Mendelian mutations in a large UK population-based Parkinson's disease study. Brain 2019, 142, 2828-2844. [CrossRef]

35. Spillantini, M.G.; Schmidt, M.L.; Lee, V.M.; Trojanowski, J.Q.; Jakes, R.; Goedert, M. Alpha-synuclein in Lewy bodies. Nature 1997, 388, 839-840. [CrossRef]

36. Conway, K.A.; Harper, J.D.; Lansbury, P.T. Accelerated in vitro fibril formation by a mutant alpha-synuclein linked to early-onset Parkinson disease. Nat. Med. 1998, 4, 1318-1320. [CrossRef]

37. Giasson, B.I.; Duda, J.E.; Murray, I.V.; Chen, Q.; Souza, J.M.; Hurtig, H.I.; Ischiropoulos, H.; Trojanowski, J.Q.; Lee, V.M. Oxidative damage linked to neurodegeneration by selective alpha-synuclein nitration in synucleinopathy lesions. Science 2000, 290, 985-989. [CrossRef]

38. Xu, J.; Kao, S.Y.; Lee, F.J.; Song, W.; Jin, L.W.; Yankner, B.A. Dopamine-dependent neurotoxicity of alpha-synuclein: A mechanism for selective neurodegeneration in Parkinson disease. Nat. Med. 2002, 8, 600-606. [CrossRef] 
39. Peelaerts, W.; Bousset, L.; Van der Perren, A.; Moskalyuk, A.; Pulizzi, R.; Giugliano, M.; Van den Haute, C.; Melki, R.; Baekelandt, V. $\alpha$-Synuclein strains cause distinct synucleinopathies after local and systemic administration. Nature 2015, 522, 340-344. [CrossRef]

40. Perrino, G.; Wilson, C.; Santorelli, M.; di Bernardo, D. Quantitative Characterization of $\alpha$-Synuclein Aggregation in Living Cells through Automated Microfluidics Feedback Control. Cell Rep. 2019, 27, 916-927.e915. [CrossRef]

41. Narkiewicz, J.; Giachin, G.; Legname, G. In vitro aggregation assays for the characterization of $\alpha$-synuclein prion-like properties. Prion 2014, 8, 19-32. [CrossRef]

42. Neystat, M.; Lynch, T.; Przedborski, S.; Kholodilov, N.; Rzhetskaya, M.; Burke, R.E. Alpha-synuclein expression in substantia nigra and cortex in Parkinson's disease. Mov. Disord. 1999, 14, 417-422. [CrossRef]

43. Wong, Y.C.; Krainc, D. $\alpha$-synuclein toxicity in neurodegeneration: Mechanism and therapeutic strategies. Nat. Med. 2017, 23, 1-13. [CrossRef]

44. Vilariño-Güell, C.; Wider, C.; Ross, O.A.; Dachsel, J.C.; Kachergus, J.M.; Lincoln, S.J.; Soto-Ortolaza, A.I.; Cobb, S.A.; Wilhoite, G.J.; Bacon, J.A.; et al. VPS35 mutations in Parkinson disease. Am. J. Hum. Genet. 2011, 89, 162-167. [CrossRef]

45. Zimprich, A.; Benet-Pagès, A.; Struhal, W.; Graf, E.; Eck, S.H.; Offman, M.N.; Haubenberger, D.; Spielberger, S.; Schulte, E.C.; Lichtner, P.; et al. A mutation in VPS35, encoding a subunit of the retromer complex, causes late-onset Parkinson disease. Am. J. Hum. Genet. 2011, 89, 168-175. [CrossRef]

46. Choy, R.W.; Park, M.; Temkin, P.; Herring, B.E.; Marley, A.; Nicoll, R.A.; von Zastrow, M. Retromer mediates a discrete route of local membrane delivery to dendrites. Neuron 2014, 82, 55-62. [CrossRef]

47. Bono, K.; Hara-Miyauchi, C.; Sumi, S.; Oka, H.; Iguchi, Y.; Okano, H.J. Endosomal dysfunction in iPSC-derived neural cells from Parkinson's disease patients with VPS35 D620N. Mol. Brain 2020, 13, 137. [CrossRef]

48. Hanss, Z.; Larsen, S.B.; Antony, P.; Mencke, P.; Massart, F.; Jarazo, J.; Schwamborn, J.C.; Barbuti, P.A.; Mellick, G.D.; Krüger, R. Mitochondrial and Clearance Impairment in p.D620N VPS35 Patient-Derived Neurons. Mov. Disord. 2020. [CrossRef]

49. Wider, C.; Skipper, L.; Solida, A.; Brown, L.; Farrer, M.; Dickson, D.; Wszolek, Z.K.; Vingerhoets, F.J. Autosomal dominant dopa-responsive parkinsonism in a multigenerational Swiss family. Parkinsonism Relat. Disord. 2008, 14, 465-470. [CrossRef]

50. Lesage, S.; Houot, M.; Mangone, G.; Tesson, C.; Bertrand, H.; Forlani, S.; Anheim, M.; Brefel-Courbon, C.; Broussolle, E.; Thobois, S.; et al. Genetic and Phenotypic Basis of Autosomal Dominant Parkinson's Disease in a Large Multi-Center Cohort. Front. Neurol. 2020, 11, 682. [CrossRef]

51. Kitada, T.; Asakawa, S.; Hattori, N.; Matsumine, H.; Yamamura, Y.; Minoshima, S.; Yokochi, M.; Mizuno, Y.; Shimizu, N. Mutations in the parkin gene cause autosomal recessive juvenile parkinsonism. Nature 1998, 392, 605-608. [CrossRef]

52. Bonifati, V.; Rizzu, P.; van Baren, M.J.; Schaap, O.; Breedveld, G.J.; Krieger, E.; Dekker, M.C.; Squitieri, F.; Ibanez, P.; Joosse, M.; et al. Mutations in the DJ-1 gene associated with autosomal recessive early-onset parkinsonism. Science 2003, 299, 256-259. [CrossRef]

53. Valente, E.M.; Abou-Sleiman, P.M.; Caputo, V.; Muqit, M.M.; Harvey, K.; Gispert, S.; Ali, Z.; Del Turco, D.; Bentivoglio, A.R.; Healy, D.G.; et al. Hereditary early-onset Parkinson's disease caused by mutations in PINK1. Science 2004, 304, 1158-1160. [CrossRef] [PubMed]

54. Zhang, Y.; Gao, J.; Chung, K.K.; Huang, H.; Dawson, V.L.; Dawson, T.M. Parkin functions as an E2-dependent ubiquitin- protein ligase and promotes the degradation of the synaptic vesicle-associated protein, CDCrel-1. Proc. Natl. Acad. Sci. USA 2000, 97, 13354-13359. [CrossRef] [PubMed]

55. Rothfuss, O.; Fischer, H.; Hasegawa, T.; Maisel, M.; Leitner, P.; Miesel, F.; Sharma, M.; Bornemann, A.; Berg, D.; Gasser, T.; et al. Parkin protects mitochondrial genome integrity and supports mitochondrial DNA repair. Hum. Mol. Genet. 2009, 18, 3832-3850. [CrossRef] [PubMed]

56. Rizzu, P.; Hinkle, D.A.; Zhukareva, V.; Bonifati, V.; Severijnen, L.A.; Martinez, D.; Ravid, R.; Kamphorst, W.; Eberwine, J.H.; Lee, V.M.; et al. DJ-1 colocalizes with tau inclusions: A link between parkinsonism and dementia. Ann. Neurol. 2004, 55, 113-118. [CrossRef] [PubMed]

57. Sliter, D.A.; Martinez, J.; Hao, L.; Chen, X.; Sun, N.; Fischer, T.D.; Burman, J.L.; Li, Y.; Zhang, Z.; Narendra, D.P.; et al. Parkin and PINK1 mitigate STING-induced inflammation. Nature 2018, 561, 258-262. [CrossRef]

58. Xiong, H.; Wang, D.; Chen, L.; Choo, Y.S.; Ma, H.; Tang, C.; Xia, K.; Jiang, W.; Ronai, Z.; Zhuang, X.; et al. Parkin, PINK1, and DJ-1 form a ubiquitin E3 ligase complex promoting unfolded protein degradation. J. Clin. Investig. 2009, 119, 650-660. [CrossRef]

59. Hayashi, S.; Wakabayashi, K.; Ishikawa, A.; Nagai, H.; Saito, M.; Maruyama, M.; Takahashi, T.; Ozawa, T.; Tsuji, S.; Takahashi, H. An autopsy case of autosomal-recessive juvenile parkinsonism with a homozygous exon 4 deletion in the parkin gene. Mov. Disord. 2000, 15, 884-888. [CrossRef]

60. Gouider-Khouja, N.; Larnaout, A.; Amouri, R.; Sfar, S.; Belal, S.; Ben Hamida, C.; Ben Hamida, M.; Hattori, N.; Mizuno, Y.; Hentati, F. Autosomal recessive parkinsonism linked to parkin gene in a Tunisian family. Clinical, genetic and pathological study. Parkinsonism Relat. Disord. 2003, 9, 247-251. [CrossRef]

61. Mori, H.; Kondo, T.; Yokochi, M.; Matsumine, H.; Nakagawa-Hattori, Y.; Miyake, T.; Suda, K.; Mizuno, Y. Pathologic and biochemical studies of juvenile parkinsonism linked to chromosome 6q. Neurology 1998, 51, 890-892. [CrossRef]

62. Miyakawa, S.; Ogino, M.; Funabe, S.; Uchino, A.; Shimo, Y.; Hattori, N.; Ichinoe, M.; Mikami, T.; Saegusa, M.; Nishiyama, K.; et al. Lewy body pathology in a patient with a homozygous parkin deletion. Mov. Disord. 2013, 28, 388-391. [CrossRef] 
63. Schneider, S.A.; Alcalay, R.N. Neuropathology of genetic synucleinopathies with parkinsonism: Review of the literature. Mov. Disord. 2017, 32, 1504-1523. [CrossRef]

64. Ramirez, A.; Heimbach, A.; Gründemann, J.; Stiller, B.; Hampshire, D.; Cid, L.P.; Goebel, I.; Mubaidin, A.F.; Wriekat, A.L.; Roeper, J.; et al. Hereditary parkinsonism with dementia is caused by mutations in ATP13A2, encoding a lysosomal type 5 P-type ATPase. Nat. Genet. 2006, 38, 1184-1191. [CrossRef]

65. van Veen, S.; Martin, S.; Van den Haute, C.; Benoy, V.; Lyons, J.; Vanhoutte, R.; Kahler, J.P.; Decuypere, J.P.; Gelders, G.; Lambie, E.; et al. ATP13A2 deficiency disrupts lysosomal polyamine export. Nature 2020, 578, 419-424. [CrossRef]

66. Di Fonzo, A.; Dekker, M.C.; Montagna, P.; Baruzzi, A.; Yonova, E.H.; Correia Guedes, L.; Szczerbinska, A.; Zhao, T.; DubbelHulsman, L.O.; Wouters, C.H.; et al. FBXO7 mutations cause autosomal recessive, early-onset parkinsonian-pyramidal syndrome. Neurology 2009, 72, 240-245. [CrossRef]

67. Wei, L.; Ding, L.; Li, H.; Lin, Y.; Dai, Y.; Xu, X.; Dong, Q.; Long, L. Juvenile-onset parkinsonism with pyramidal signs due to compound heterozygous mutations in the F-Box only protein 7 gene. Parkinsonism Relat. Disord. 2018, 47, 76-79. [CrossRef]

68. Jin, X.; An, L.; Hao, S.; Liu, Q.; Zhang, Q.; Wang, X.; Feng, X.; Zhang, C.; Cao, X.; Yan, Y.; et al. Compound heterozygous variants of the FBXO7 gene resulting in infantile-onset Parkinsonian-pyramidal syndrome in siblings of a Chinese family. J. Clin. Lab. Anal. 2020, 34, e23324. [CrossRef]

69. Liu, Y.; Lear, T.B.; Verma, M.; Wang, K.Z.; Otero, P.A.; McKelvey, A.C.; Dunn, S.R.; Steer, E.; Bateman, N.W.; Wu, C.; et al. Chemical inhibition of FBXO7 reduces inflammation and confers neuroprotection by stabilizing the mitochondrial kinase PINK1. JCI Insights 2020, 5. [CrossRef]

70. Morgan, N.V.; Westaway, S.K.; Morton, J.E.; Gregory, A.; Gissen, P.; Sonek, S.; Cangul, H.; Coryell, J.; Canham, N.; Nardocci, N.; et al. PLA2G6, encoding a phospholipase A2, is mutated in neurodegenerative disorders with high brain iron. Nat. Genet. 2006, 38, 752-754. [CrossRef]

71. Paisan-Ruiz, C.; Bhatia, K.P.; Li, A.; Hernandez, D.; Davis, M.; Wood, N.W.; Hardy, J.; Houlden, H.; Singleton, A.; Schneider, S.A. Characterization of PLA2G6 as a locus for dystonia-parkinsonism. Ann. Neurol. 2009, 65, 19-23. [CrossRef]

72. Chu, Y.T.; Lin, H.Y.; Chen, P.L.; Lin, C.H. Genotype-phenotype correlations of adult-onset PLA2G6-associated Neurodegeneration: Case series and literature review. BMC Neurol. 2020, 20, 101. [CrossRef]

73. Quadri, M.; Fang, M.; Picillo, M.; Olgiati, S.; Breedveld, G.J.; Graafland, J.; Wu, B.; Xu, F.; Erro, R.; Amboni, M.; et al. Mutation in the SYNJ1 gene associated with autosomal recessive, early-onset Parkinsonism. Hum. Mutat. 2013, 34, 1208-1215. [CrossRef]

74. Krebs, C.E.; Karkheiran, S.; Powell, J.C.; Cao, M.; Makarov, V.; Darvish, H.; Di Paolo, G.; Walker, R.H.; Shahidi, G.A.; Buxbaum, J.D.; et al. The Sac1 domain of SYNJ1 identified mutated in a family with early-onset progressive Parkinsonism with generalized seizures. Hum. Mutat. 2013, 34, 1200-1207. [CrossRef]

75. Deng, H.X.; Shi, Y.; Yang, Y.; Ahmeti, K.B.; Miller, N.; Huang, C.; Cheng, L.; Zhai, H.; Deng, S.; Nuytemans, K.; et al. Identification of TMEM230 mutations in familial Parkinson's disease. Nat. Genet. 2016, 48, 733-739. [CrossRef]

76. Wang, X.; Whelan, E.; Liu, Z.; Liu, C.F.; Smith, W.W. Controversy of TMEM230 Associated with Parkinson's Disease. Neuroscience 2021, 453, 280-286. [CrossRef]

77. Saini, P.; Rudakou, U.; Yu, E.; Ruskey, J.A.; Asayesh, F.; Laurent, S.B.; Spiegelman, D.; Fahn, S.; Waters, C.; Monchi, O.; et al. Association study of DNAJC13, UCHL1, HTRA2, GIGYF2, and EIF4G1 with Parkinson's disease. Neurobiol. Aging 2020. [CrossRef] [PubMed]

78. Paisán-Ruíz, C.; Jain, S.; Evans, E.W.; Gilks, W.P.; Simón, J.; van der Brug, M.; López de Munain, A.; Aparicio, S.; Gil, A.M.; Khan, N.; et al. Cloning of the gene containing mutations that cause PARK8-linked Parkinson's disease. Neuron 2004, 44, 595-600. [CrossRef] [PubMed]

79. Zimprich, A.; Biskup, S.; Leitner, P.; Lichtner, P.; Farrer, M.; Lincoln, S.; Kachergus, J.; Hulihan, M.; Uitti, R.J.; Calne, D.B.; et al. Mutations in LRRK2 cause autosomal-dominant parkinsonism with pleomorphic pathology. Neuron 2004, 44, 601-607. [CrossRef] [PubMed]

80. Marder, K.; Wang, Y.; Alcalay, R.N.; Mejia-Santana, H.; Tang, M.X.; Lee, A.; Raymond, D.; Mirelman, A.; Saunders-Pullman, R.; Clark, L.; et al. Age-specific penetrance of LRRK2 G2019S in the Michael J. Fox Ashkenazi Jewish LRRK2 Consortium. Neurology 2015, 85, 89-95. [CrossRef] [PubMed]

81. Lee, A.J.; Wang, Y.; Alcalay, R.N.; Mejia-Santana, H.; Saunders-Pullman, R.; Bressman, S.; Corvol, J.C.; Brice, A.; Lesage, S.; Mangone, G.; et al. Penetrance estimate of LRRK2 p.G2019S mutation in individuals of non-Ashkenazi Jewish ancestry. Mov. Disord. 2017, 32, 1432-1438. [CrossRef]

82. Healy, D.G.; Falchi, M.; O'Sullivan, S.S.; Bonifati, V.; Durr, A.; Bressman, S.; Brice, A.; Aasly, J.; Zabetian, C.P.; Goldwurm, S.; et al. Phenotype, genotype, and worldwide genetic penetrance of LRRK2-associated Parkinson's disease: A case-control study. Lancet Neurol. 2008, 7, 583-590. [CrossRef]

83. Shu, L.; Zhang, Y.; Pan, H.; Xu, Q.; Guo, J.; Tang, B.; Sun, Q. Clinical Heterogeneity Among. Front. Aging Neurosci. 2018, 10, 283. [CrossRef]

84. Di Fonzo, A.; Tassorelli, C.; De Mari, M.; Chien, H.F.; Ferreira, J.; Rohé, C.F.; Riboldazzi, G.; Antonini, A.; Albani, G.; Mauro, A.; et al. Comprehensive analysis of the LRRK2 gene in sixty families with Parkinson's disease. Eur. J. Hum. Genet. 2006, 14, 322-331. [CrossRef]

85. Lüth, T.; König, I.R.; Grünewald, A.; Kasten, M.; Klein, C.; Hentati, F.; Farrer, M.; Trinh, J. Age at Onset of LRRK2 p.Gly2019Ser Is Related to Environmental and Lifestyle Factors. Mov. Disord. 2020, 35, 1854-1858. [CrossRef] 
86. San Luciano, M.; Tanner, C.M.; Meng, C.; Marras, C.; Goldman, S.M.; Lang, A.E.; Tolosa, E.; Schüle, B.; Langston, J.W.; Brice, A.; et al. Nonsteroidal Anti-inflammatory Use and LRRK2 Parkinson's Disease Penetrance. Mov. Disord. 2020, 35, 1755-1764. [CrossRef]

87. Heckman, M.G.; Labbé, C.; Kolicheski, A.L.; Soto-Beasley, A.I.; Walton, R.L.; Valentino, R.R.; Brennan, E.R.; Johnson, P.W.; Baheti, S.; Sarangi, V.; et al. Fine-mapping of the non-coding variation driving the Caucasian LRRK2 GWAS signal in Parkinson's disease. Parkinsonism Relat. Disord. 2021, 83, 22-30. [CrossRef]

88. Hentati, F.; Trinh, J.; Thompson, C.; Nosova, E.; Farrer, M.J.; Aasly, J.O. LRRK2 parkinsonism in Tunisia and Norway: A comparative analysis of disease penetrance. Neurology 2014, 83, 568-569. [CrossRef]

89. Lai, D.; Alipanahi, B.; Fontanillas, P.; Schwantes-An, T.H.; Aasly, J.; Alcalay, R.N.; Beecham, G.W.; Berg, D.; Bressman, S.; Brice, A.; et al. Genomewide Association Studies of LRRK2 Modifiers of Parkinson's Disease. Ann. Neurol. 2021. [CrossRef]

90. Shu, L.; Zhang, Y.; Sun, Q.; Pan, H.; Tang, B. A Comprehensive Analysis of Population Differences in. Front. Aging Neurosci. 2019, 11, 13. [CrossRef]

91. Trinh, J.; Zeldenrust, F.M.J.; Huang, J.; Kasten, M.; Schaake, S.; Petkovic, S.; Madoev, H.; Grünewald, A.; Almuammar, S.; König, I.R.; et al. Genotype-phenotype relations for the Parkinson's disease genes SNCA, LRRK2, VPS35: MDSGene systematic review. Mov. Disord. 2018, 33, 1857-1870. [CrossRef]

92. Berwick, D.C.; Heaton, G.R.; Azeggagh, S.; Harvey, K. LRRK2 Biology from structure to dysfunction: Research progresses, but the themes remain the same. Mol. Neurodegener. 2019, 14, 49. [CrossRef]

93. Howlett, E.H.; Jensen, N.; Belmonte, F.; Zafar, F.; Hu, X.; Kluss, J.; Schüle, B.; Kaufman, B.A.; Greenamyre, J.T.; Sanders, L.H. LRRK2 G2019S-induced mitochondrial DNA damage is LRRK2 kinase dependent and inhibition restores mtDNA integrity in Parkinson's disease. Hum. Mol. Genet. 2017, 26, 4340-4351. [CrossRef]

94. Lee, B.D.; Shin, J.H.; VanKampen, J.; Petrucelli, L.; West, A.B.; Ko, H.S.; Lee, Y.I.; Maguire-Zeiss, K.A.; Bowers, W.J.; Federoff, H.J.; et al. Inhibitors of leucine-rich repeat kinase-2 protect against models of Parkinson's disease. Nat. Med. 2010, 16, 998-1000. [CrossRef] [PubMed]

95. Di Maio, R.; Hoffman, E.K.; Rocha, E.M.; Keeney, M.T.; Sanders, L.H.; De Miranda, B.R.; Zharikov, A.; Van Laar, A.; Stepan, A.F.; Lanz, T.A.; et al. LRRK2 activation in idiopathic Parkinson's disease. Sci. Transl. Med. 2018, 10. [CrossRef] [PubMed]

96. Andersen, M.A.; Wegener, K.M.; Larsen, S.; Badolo, L.; Smith, G.P.; Jeggo, R.; Jensen, P.H.; Sotty, F.; Christensen, K.V.; Thougaard, A. PFE-360-induced LRRK2 inhibition induces reversible, non-adverse renal changes in rats. Toxicology 2018, 395, 15-22. [CrossRef]

97. Lebovitz, C.; Wretham, N.; Osooly, M.; Milne, K.; Dash, T.; Thornton, S.; Tessier-Cloutier, B.; Sathiyaseelan, P.; Bortnik, S.; Go, N.E.; et al. Loss of Parkinson's susceptibility gene LRRK2 promotes carcinogen-induced lung tumorigenesis. Sci. Rep. 2021, 11, 2097. [CrossRef]

98. Whiffin, N.; Armean, I.M.; Kleinman, A.; Marshall, J.L.; Minikel, E.V.; Goodrich, J.K.; Quaife, N.M.; Cole, J.B.; Wang, Q.; Karczewski, K.J.; et al. The effect of LRRK2 loss-of-function variants in humans. Nat. Med. 2020, 26, 869-877. [CrossRef] [PubMed]

99. Blauwendraat, C.; Reed, X.; Kia, D.A.; Gan-Or, Z.; Lesage, S.; Pihlstrøm, L.; Guerreiro, R.; Gibbs, J.R.; Sabir, M.; Ahmed, S.; et al. Frequency of Loss of Function Variants in LRRK2 in Parkinson Disease. JAMA Neurol. 2018, 75, 1416-1422. [CrossRef] [PubMed]

100. Neudorfer, O.; Giladi, N.; Elstein, D.; Abrahamov, A.; Turezkite, T.; Aghai, E.; Reches, A.; Bembi, B.; Zimran, A. Occurrence of Parkinson's syndrome in type I Gaucher disease. QJM 1996, 89, 691-694. [CrossRef] [PubMed]

101. Goker-Alpan, O.; Schiffmann, R.; LaMarca, M.E.; Nussbaum, R.L.; McInerney-Leo, A.; Sidransky, E. Parkinsonism among Gaucher disease carriers. J. Med. Genet. 2004, 41, 937-940. [CrossRef]

102. Sidransky, E.; Nalls, M.A.; Aasly, J.O.; Aharon-Peretz, J.; Annesi, G.; Barbosa, E.R.; Bar-Shira, A.; Berg, D.; Bras, J.; Brice, A.; et al. Multicenter analysis of glucocerebrosidase mutations in Parkinson's disease. N. Engl. J. Med. 2009, 361, 1651-1661. [CrossRef]

103. Hruska, K.S.; LaMarca, M.E.; Scott, C.R.; Sidransky, E. Gaucher disease: Mutation and polymorphism spectrum in the glucocerebrosidase gene (GBA). Hum. Mutat. 2008, 29, 567-583. [CrossRef]

104. CENTOGENE. CENTOGENE. The Rare Disease Company. Introducing CentoLSD ${ }^{\mathrm{TM}}$. 2021. Available online: https://www. centogene.com/es / centolsd.html (accessed on 26 June 2021).

105. Alcalay, R.N.; Dinur, T.; Quinn, T.; Sakanaka, K.; Levy, O.; Waters, C.; Fahn, S.; Dorovski, T.; Chung, W.K.; Pauciulo, M.; et al. Comparison of Parkinson risk in Ashkenazi Jewish patients with Gaucher disease and GBA heterozygotes. JAMA Neurol. 2014, 71, 752-757. [CrossRef]

106. Anheim, M.; Elbaz, A.; Lesage, S.; Durr, A.; Condroyer, C.; Viallet, F.; Pollak, P.; Bonaïti, B.; Bonaïti-Pellié, C.; Brice, A.; et al. Penetrance of Parkinson disease in glucocerebrosidase gene mutation carriers. Neurology 2012, 78, 417-420. [CrossRef]

107. Sidransky, E.; Hart, P.S. Penetrance of PD in Glucocerebrosidase Gene Mutation Carriers. Neurology 2012, 79, 106-107. [CrossRef]

108. Zhang, Y.; Shu, L.; Sun, Q.; Zhou, X.; Pan, H.; Guo, J.; Tang, B. Integrated Genetic Analysis of Racial Differences of Common. Front. Mol. Neurosci. 2018, 11, 43. [CrossRef]

109. Gan-Or, Z.; Amshalom, I.; Kilarski, L.L.; Bar-Shira, A.; Gana-Weisz, M.; Mirelman, A.; Marder, K.; Bressman, S.; Giladi, N.; Orr-Urtreger, A. Differential effects of severe vs mild GBA mutations on Parkinson disease. Neurology 2015, 84, 880-887. [CrossRef]

110. Mallett, V.; Ross, J.P.; Alcalay, R.N.; Ambalavanan, A.; Sidransky, E.; Dion, P.A.; Rouleau, G.A.; Gan-Or, Z. GBA p.T369M substitution in Parkinson disease: Polymorphism or association? A meta-analysis. Neurol. Genet. 2016, 2, e104. [CrossRef]

111. Duran, R.; Mencacci, N.E.; Angeli, A.V.; Shoai, M.; Deas, E.; Houlden, H.; Mehta, A.; Hughes, D.; Cox, T.M.; Deegan, P.; et al. The glucocerobrosidase E326K variant predisposes to Parkinson's disease, but does not cause Gaucher's disease. Mov. Disord. 2013, 28, 232-236. [CrossRef] 
112. Park, J.K.; Tayebi, N.; Stubblefield, B.K.; LaMarca, M.E.; MacKenzie, J.J.; Stone, D.L.; Sidransky, E. The E326K mutation and Gaucher disease: Mutation or polymorphism? Clin. Genet. 2002, 61, 32-34. [CrossRef]

113. Blauwendraat, C.; Reed, X.; Krohn, L.; Heilbron, K.; Bandres-Ciga, S.; Tan, M.; Gibbs, J.R.; Hernandez, D.G.; Kumaran, R.; Langston, R.; et al. Genetic modifiers of risk and age at onset in GBA associated Parkinson's disease and Lewy body dementia. Brain 2020, 143, 234-248. [CrossRef]

114. Ruskey, J.A.; Greenbaum, L.; Roncière, L.; Alam, A.; Spiegelman, D.; Liong, C.; Levy, O.A.; Waters, C.; Fahn, S.; Marder, K.S.; et al. Increased yield of full GBA sequencing in Ashkenazi Jews with Parkinson's disease. Eur. J. Med. Genet. 2019, 62, 65-69. [CrossRef]

115. Zampieri, S.; Cattarossi, S.; Bembi, B.; Dardis, A. GBA Analysis in Next-Generation Era: Pitfalls, Challenges, and Possible Solutions. J. Mol. Diagn. 2017, 19, 733-741. [CrossRef]

116. Leija-Salazar, M.; Sedlazeck, F.J.; Toffoli, M.; Mullin, S.; Mokretar, K.; Athanasopoulou, M.; Donald, A.; Sharma, R.; Hughes, D.; Schapira, A.H.V.; et al. Evaluation of the detection of GBA missense mutations and other variants using the Oxford Nanopore MinION. Mol. Genet. Genom. Med. 2019, 7, e564. [CrossRef]

117. Zhang, Y.; Shu, L.; Zhou, X.; Pan, H.; Xu, Q.; Guo, J.; Tang, B.; Sun, Q. A Meta-Analysis of. Parkinsons Dis. 2018, $2018,3136415$. [CrossRef]

118. Gan-Or, Z.; Giladi, N.; Rozovski, U.; Shifrin, C.; Rosner, S.; Gurevich, T.; Bar-Shira, A.; Orr-Urtreger, A. Genotype-phenotype correlations between GBA mutations and Parkinson disease risk and onset. Neurology 2008, 70, 2277-2283. [CrossRef]

119. Maple-Grødem, J.; Dalen, I.; Tysnes, O.B.; Macleod, A.D.; Forsgren, L.; Counsell, C.E.; Alves, G. Association of GBA Genotype with Motor and Functional Decline in Newly Diagnosed Patients with Parkinsons Disease. Neurology 2020. [CrossRef]

120. Cilia, R.; Tunesi, S.; Marotta, G.; Cereda, E.; Siri, C.; Tesei, S.; Zecchinelli, A.L.; Canesi, M.; Mariani, C.B.; Meucci, N.; et al. Survival and dementia in GBA-associated Parkinson's disease: The mutation matters. Ann. Neurol. 2016, 80, 662-673. [CrossRef]

121. Jesús, S.; Huertas, I.; Bernal-Bernal, I.; Bonilla-Toribio, M.; Cáceres-Redondo, M.T.; Vargas-González, L.; Gómez-Llamas, M.; Carrillo, F.; Calderón, E.; Carballo, M.; et al. GBA Variants Influence Motor and Non-Motor Features of Parkinson's Disease. PLoS ONE 2016, 11, e0167749. [CrossRef]

122. Iwaki, H.; Blauwendraat, C.; Leonard, H.L.; Kim, J.J.; Liu, G.; Maple-Grødem, J.; Corvol, J.C.; Pihlstrøm, L.; van Nimwegen, M.; Hutten, S.J.; et al. Genomewide association study of Parkinson's disease clinical biomarkers in 12 longitudinal patients' cohorts. Mov. Disord. 2019, 34, 1839-1850. [CrossRef] [PubMed]

123. Iwaki, H.; Blauwendraat, C.; Leonard, H.L.; Liu, G.; Maple-Grødem, J.; Corvol, J.C.; Pihlstrøm, L.; van Nimwegen, M.; Hutten, S.J.; Nguyen, K.H.; et al. Genetic risk of Parkinson disease and progression: An analysis of 13 longitudinal cohorts. Neurol. Genet. 2019, 5, e348. [CrossRef] [PubMed]

124. Gan-Or, Z.; Liong, C.; Alcalay, R.N. GBA-Associated Parkinson's Disease and Other Synucleinopathies. Curr. Neurol. Neurosci. Rep. 2018, 18, 44. [CrossRef] [PubMed]

125. Alcalay, R.N.; Levy, O.A.; Waters, C.C.; Fahn, S.; Ford, B.; Kuo, S.H.; Mazzoni, P.; Pauciulo, M.W.; Nichols, W.C.; Gan-Or, Z.; et al. Glucocerebrosidase activity in Parkinson's disease with and without GBA mutations. Brain 2015, 138, 2648-2658. [CrossRef]

126. Hallett, P.J.; Huebecker, M.; Brekk, O.R.; Moloney, E.B.; Rocha, E.M.; Priestman, D.A.; Platt, F.M.; Isacson, O. Glycosphingolipid levels and glucocerebrosidase activity are altered in normal aging of the mouse brain. Neurobiol. Aging 2018, 67, 189-200. [CrossRef]

127. Parnetti, L.; Chiasserini, D.; Persichetti, E.; Eusebi, P.; Varghese, S.; Qureshi, M.M.; Dardis, A.; Deganuto, M.; De Carlo, C.; Castrioto, A.; et al. Cerebrospinal fluid lysosomal enzymes and alpha-synuclein in Parkinson's disease. Mov. Disord. 2014, 29, 1019-1027. [CrossRef]

128. Wang, Y.; Clark, L.N.; Louis, E.D.; Mejia-Santana, H.; Harris, J.; Cote, L.J.; Waters, C.; Andrews, H.; Ford, B.; Frucht, S.; et al. Risk of Parkinson disease in carriers of parkin mutations: Estimation using the kin-cohort method. Arch. Neurol. 2008, 65, 467-474. [CrossRef]

129. Oliveira, S.A.; Scott, W.K.; Martin, E.R.; Nance, M.A.; Watts, R.L.; Hubble, J.P.; Koller, W.C.; Pahwa, R.; Stern, M.B.; Hiner, B.C.; et al. Parkin mutations and susceptibility alleles in late-onset Parkinson's disease. Ann. Neurol. 2003, 53, 624-629. [CrossRef]

130. Lücking, C.B.; Dürr, A.; Bonifati, V.; Vaughan, J.; De Michele, G.; Gasser, T.; Harhangi, B.S.; Meco, G.; Denèfle, P.; Wood, N.W.; et al. Association between early-onset Parkinson's disease and mutations in the parkin gene. N. Engl. J. Med. 2000, 342, $1560-1567$. [CrossRef]

131. Yu, E.; Rudakou, U.; Krohn, L.; Mufti, K.; Ruskey, J.A.; Asayesh, F.; Estiar, M.A.; Spiegelman, D.; Surface, M.; Fahn, S.; et al. Analysis of Heterozygous PRKN Variants and Copy-Number Variations in Parkinson's Disease. Mov. Disord. 2021, 36, 178-187. [CrossRef]

132. MacArthur, J.; Bowler, E.; Cerezo, M.; Gil, L.; Hall, P.; Hastings, E.; Junkins, H.; McMahon, A.; Milano, A.; Morales, J.; et al. The new NHGRI-EBI Catalog of published genome-wide association studies (GWAS Catalog). Nucleic Acids Res. 2017, 45, D896-D901. [CrossRef]

133. Yengo, L.; Sidorenko, J.; Kemper, K.E.; Zheng, Z.; Wood, A.R.; Weedon, M.N.; Frayling, T.M.; Hirschhorn, J.; Yang, J.; Visscher, P.M.; et al. Meta-analysis of genome-wide association studies for height and body mass index in $\sim 700,000$ individuals of European ancestry. Hum. Mol. Genet. 2018, 27, 3641-3649. [CrossRef]

134. Vujkovic, M.; Keaton, J.M.; Lynch, J.A.; Miller, D.R.; Zhou, J.; Tcheandjieu, C.; Huffman, J.E.; Assimes, T.L.; Lorenz, K.; Zhu, X.; et al. Discovery of 318 new risk loci for type 2 diabetes and related vascular outcomes among 1.4 million participants in a multi-ancestry meta-analysis. Nat. Genet. 2020, 52, 680-691. [CrossRef] 
135. Kao, P.Y.; Leung, K.H.; Chan, L.W.; Yip, S.P.; Yap, M.K. Pathway analysis of complex diseases for GWAS, extending to consider rare variants, multi-omics and interactions. Biochim. Biophys. Acta Gen. Subj. 2017, 1861, 335-353. [CrossRef]

136. Nalls, M.A.; Pankratz, N.; Lill, C.M.; Do, C.B.; Hernandez, D.G.; Saad, M.; DeStefano, A.L.; Kara, E.; Bras, J.; Sharma, M.; et al. Large-scale meta-analysis of genome-wide association data identifies six new risk loci for Parkinson's disease. Nat. Genet. 2014, 46, 989-993. [CrossRef]

137. Escott-Price, V.; Nalls, M.A.; Morris, H.R.; Lubbe, S.; Brice, A.; Gasser, T.; Heutink, P.; Wood, N.W.; Hardy, J.; Singleton, A.B.; et al. Polygenic risk of Parkinson disease is correlated with disease age at onset. Ann. Neurol. 2015, 77, 582-591. [CrossRef]

138. Ibanez, L.; Dube, U.; Saef, B.; Budde, J.; Black, K.; Medvedeva, A.; Del-Aguila, J.L.; Davis, A.A.; Perlmutter, J.S.; Harari, O.; et al. Parkinson disease polygenic risk score is associated with Parkinson disease status and age at onset but not with alpha-synuclein cerebrospinal fluid levels. BMC Neurol. 2017, 17, 198. [CrossRef]

139. Li, W.W.; Fan, D.Y.; Shen, Y.Y.; Zhou, F.Y.; Chen, Y.; Wang, Y.R.; Yang, H.; Mei, J.; Li, L.; Xu, Z.Q.; et al. Association of the Polygenic Risk Score with the Incidence Risk of Parkinson's Disease and Cerebrospinal Fluid $\alpha$-Synuclein in a Chinese Cohort. Neurotox. Res. 2019, 36, 515-522. [CrossRef]

140. Jacobs, B.M.; Belete, D.; Bestwick, J.; Blauwendraat, C.; Bandres-Ciga, S.; Heilbron, K.; Dobson, R.; Nalls, M.A.; Singleton, A.; Hardy, J.; et al. Parkinson's disease determinants, prediction and gene-environment interactions in the UK Biobank. J. Neurol. Neurosurg. Psychiatry 2020, 91, 1046-1054. [CrossRef]

141. Foo, J.N.; Chew, E.G.Y.; Chung, S.J.; Peng, R.; Blauwendraat, C.; Nalls, M.A.; Mok, K.Y.; Satake, W.; Toda, T.; Chao, Y.; et al. Identification of Risk Loci for Parkinson Disease in Asians and Comparison of Risk Between Asians and Europeans: A GenomeWide Association Study. JAMA Neurol. 2020, 77, 746-754. [CrossRef]

142. Molparia, B.; Schrader, B.N.; Cohen, E.; Wagner, J.L.; Gupta, S.R.; Gould, S.; Hwynn, N.; Spencer, E.G.; Torkamani, A. Combined accelerometer and genetic analysis to differentiate essential tremor from Parkinson's disease. PeerJ 2018, 6, e5308. [CrossRef]

143. Bandres-Ciga, S.; Saez-Atienzar, S.; Kim, J.J.; Makarious, M.B.; Faghri, F.; Diez-Fairen, M.; Iwaki, H.; Leonard, H.; Botia, J.; Ryten, M.; et al. Large-scale pathway specific polygenic risk and transcriptomic community network analysis identifies novel functional pathways in Parkinson disease. Acta Neuropathol. 2020, 140, 341-358. [CrossRef]

144. Pankratz, N.; Beecham, G.W.; DeStefano, A.L.; Dawson, T.M.; Doheny, K.F.; Factor, S.A.; Hamza, T.H.; Hung, A.Y.; Hyman, B.T.; Ivinson, A.J.; et al. Meta-analysis of Parkinson's disease: Identification of a novel locus, RIT2. Ann. Neurol. 2012, 71, 370-384. [CrossRef]

145. Rudakou, U.; Yu, E.; Krohn, L.; Ruskey, J.A.; Asayesh, F.; Dauvilliers, Y.; Spiegelman, D.; Greenbaum, L.; Fahn, S.; Waters, C.H.; et al. Targeted sequencing of Parkinson's disease loci genes highlights SYT11, FGF20 and other associations. Brain 2021, 144, 462-472. [CrossRef]

146. Fung, H.C.; Scholz, S.; Matarin, M.; Simón-Sánchez, J.; Hernandez, D.; Britton, A.; Gibbs, J.R.; Langefeld, C.; Stiegert, M.L.; Schymick, J.; et al. Genome-wide genotyping in Parkinson's disease and neurologically normal controls: First stage analysis and public release of data. Lancet Neurol. 2006, 5, 911-916. [CrossRef]

147. Pankratz, N.; Wilk, J.B.; Latourelle, J.C.; DeStefano, A.L.; Halter, C.; Pugh, E.W.; Doheny, K.F.; Gusella, J.F.; Nichols, W.C.; Foroud, T.; et al. Genomewide association study for susceptibility genes contributing to familial Parkinson disease. Hum. Genet. 2009, 124, 593-605. [CrossRef]

148. Latourelle, J.C.; Pankratz, N.; Dumitriu, A.; Wilk, J.B.; Goldwurm, S.; Pezzoli, G.; Mariani, C.B.; DeStefano, A.L.; Halter, C.; Gusella, J.F.; et al. Genomewide association study for onset age in Parkinson disease. BMC Med. Genet. 2009, 10, 98. [CrossRef]

149. Satake, W.; Nakabayashi, Y.; Mizuta, I.; Hirota, Y.; Ito, C.; Kubo, M.; Kawaguchi, T.; Tsunoda, T.; Watanabe, M.; Takeda, A.; et al. Genome-wide association study identifies common variants at four loci as genetic risk factors for Parkinson's disease. Nat. Genet. 2009, 41, 1303-1307. [CrossRef]

150. Simón-Sánchez, J.; Schulte, C.; Bras, J.M.; Sharma, M.; Gibbs, J.R.; Berg, D.; Paisan-Ruiz, C.; Lichtner, P.; Scholz, S.W.; Hernandez, D.G.; et al. Genome-wide association study reveals genetic risk underlying Parkinson's disease. Nat. Genet. 2009, 41, 1308-1312. [CrossRef]

151. Edwards, T.L.; Scott, W.K.; Almonte, C.; Burt, A.; Powell, E.H.; Beecham, G.W.; Wang, L.; Züchner, S.; Konidari, I.; Wang, G.; et al. Genome-wide association study confirms SNPs in SNCA and the MAPT region as common risk factors for Parkinson disease. Ann. Hum. Genet. 2010, 74, 97-109. [CrossRef]

152. Hamza, T.H.; Zabetian, C.P.; Tenesa, A.; Laederach, A.; Montimurro, J.; Yearout, D.; Kay, D.M.; Doheny, K.F.; Paschall, J.; Pugh, E.; et al. Common genetic variation in the HLA region is associated with late-onset sporadic Parkinson's disease. Nat. Genet. 2010, 42, 781-785. [CrossRef] [PubMed]

153. Saad, M.; Lesage, S.; Saint-Pierre, A.; Corvol, J.C.; Zelenika, D.; Lambert, J.C.; Vidailhet, M.; Mellick, G.D.; Lohmann, E.; Durif, F.; et al. Genome-wide association study confirms BST1 and suggests a locus on 12q24 as the risk loci for Parkinson's disease in the European population. Hum. Mol. Genet. 2011, 20, 615-627. [CrossRef] [PubMed]

154. Simón-Sánchez, J.; van Hilten, J.J.; van de Warrenburg, B.; Post, B.; Berendse, H.W.; Arepalli, S.; Hernandez, D.G.; de Bie, R.M.; Velseboer, D.; Scheffer, H.; et al. Genome-wide association study confirms extant PD risk loci among the Dutch. Eur. J. Hum. Genet. 2011, 19, 655-661. [CrossRef]

155. Liu, X.; Cheng, R.; Verbitsky, M.; Kisselev, S.; Browne, A.; Mejia-Sanatana, H.; Louis, E.D.; Cote, L.J.; Andrews, H.; Waters, C.; et al. Genome-wide association study identifies candidate genes for Parkinson's disease in an Ashkenazi Jewish population. BMC Med. Genet. 2011, 12, 104. [CrossRef] 
156. Spencer, C.C.; Plagnol, V.; Strange, A.; Gardner, M.; Paisan-Ruiz, C.; Band, G.; Barker, R.A.; Bellenguez, C.; Bhatia, K.; Blackburn, $\mathrm{H}$.; et al. Dissection of the genetics of Parkinson's disease identifies an additional association 5' of SNCA and multiple associated haplotypes at 17q21. Hum. Mol. Genet. 2011, 20,345-353. [CrossRef]

157. Nalls, M.A.; Plagnol, V.; Hernandez, D.G.; Sharma, M.; Sheerin, U.M.; Saad, M.; Simón-Sánchez, J.; Schulte, C.; Lesage, S.; Sveinbjörnsdóttir, S.; et al. Imputation of sequence variants for identification of genetic risks for Parkinson's disease: A meta-analysis of genome-wide association studies. Lancet 2011, 377, 641-649. [CrossRef]

158. Do, C.B.; Tung, J.Y.; Dorfman, E.; Kiefer, A.K.; Drabant, E.M.; Francke, U.; Mountain, J.L.; Goldman, S.M.; Tanner, C.M.; Langston, J.W.; et al. Web-based genome-wide association study identifies two novel loci and a substantial genetic component for Parkinson's disease. PLoS Genet. 2011, 7, e1002141. [CrossRef]

159. Chung, S.J.; Armasu, S.M.; Biernacka, J.M.; Anderson, K.J.; Lesnick, T.G.; Rider, D.N.; Cunningham, J.M.; Eric Ahlskog, J.; Frigerio, R.; Maraganore, D.M. Genomic determinants of motor and cognitive outcomes in Parkinson's disease. Parkinsonism Relat. Disord. 2012, 18, 881-886. [CrossRef]

160. Hernandez, D.G.; Nalls, M.A.; Ylikotila, P.; Keller, M.; Hardy, J.A.; Majamaa, K.; Singleton, A.B. Genome wide assessment of young onset Parkinson's disease from Finland. PLoS ONE 2012, 7, e41859. [CrossRef]

161. Davis, M.F.; Cummings, A.C.; D'Aoust, L.N.; Jiang, L.; Velez Edwards, D.R.; Laux, R.; Reinhart-Mercer, L.; Fuzzell, D.; Scott, W.K.; Pericak-Vance, M.A.; et al. Parkinson disease loci in the mid-western Amish. Hum. Genet. 2013, 132, 1213-1221. [CrossRef]

162. Hill-Burns, E.M.; Wissemann, W.T.; Hamza, T.H.; Factor, S.A.; Zabetian, C.P.; Payami, H. Identification of a novel Parkinson's disease locus via stratified genome-wide association study. BMC Genom. 2014, 15, 118. [CrossRef] [PubMed]

163. Hu, Y.; Deng, L.; Zhang, J.; Fang, X.; Mei, P.; Cao, X.; Lin, J.; Wei, Y.; Zhang, X.; Xu, R. A Pooling Genome-Wide Association Study Combining a Pathway Analysis for Typical Sporadic Parkinson's Disease in the Han Population of Chinese Mainland. Mol. Neurobiol. 2016, 53, 4302-4318. [CrossRef] [PubMed]

164. Hill-Burns, E.M.; Ross, O.A.; Wissemann, W.T.; Soto-Ortolaza, A.I.; Zareparsi, S.; Siuda, J.; Lynch, T.; Wszolek, Z.K.; Silburn, P.A.; Mellick, G.D.; et al. Identification of genetic modifiers of age-at-onset for familial Parkinson's disease. Hum. Mol. Genet. 2016, 25, 3849-3862. [CrossRef]

165. Siitonen, A.; Nalls, M.A.; Hernández, D.; Gibbs, J.R.; Ding, J.; Ylikotila, P.; Edsall, C.; Singleton, A.; Majamaa, K. Genetics of early-onset Parkinson's disease in Finland: Exome sequencing and genome-wide association study. Neurobiol. Aging 2017, 53, 195.e7-195.e10. [CrossRef]

166. Foo, J.N.; Tan, L.C.; Irwan, I.D.; Au, W.L.; Low, H.Q.; Prakash, K.M.; Ahmad-Annuar, A.; Bei, J.; Chan, A.Y.; Chen, C.M.; et al. Genome-wide association study of Parkinson's disease in East Asians. Hum. Mol. Genet. 2017, 26, 226-232. [CrossRef]

167. Chang, D.; Nalls, M.A.; Hallgrímsdóttir, I.B.; Hunkapiller, J.; van der Brug, M.; Cai, F.; Kerchner, G.A.; Ayalon, G.; Bingol, B.; Sheng, M.; et al. A meta-analysis of genome-wide association studies identifies 17 new Parkinson's disease risk loci. Nat. Genet. 2017, 49, 1511-1516. [CrossRef]

168. Wallen, Z.D.; Chen, H.; Hill-Burns, E.M.; Factor, S.A.; Zabetian, C.P.; Payami, H. Plasticity-related gene 3. Neurol. Genet. 2018, 4, e271. [CrossRef]

169. Blauwendraat, C.; Heilbron, K.; Vallerga, C.L.; Bandres-Ciga, S.; von Coelln, R.; Pihlstrøm, L.; Simón-Sánchez, J.; Schulte, C.; Sharma, M.; Krohn, L.; et al. Parkinson's disease age at onset genome-wide association study: Defining heritability, genetic loci, and $\alpha$-synuclein mechanisms. Mov. Disord. 2019, 34, 866-875. [CrossRef]

170. Bandres-Ciga, S.; Ahmed, S.; Sabir, M.S.; Blauwendraat, C.; Adarmes-Gómez, A.D.; Bernal-Bernal, I.; Bonilla-Toribio, M.; Buiza-Rueda, D.; Carrillo, F.; Carrión-Claro, M.; et al. The Genetic Architecture of Parkinson Disease in Spain: Characterizing Population-Specific Risk, Differential Haplotype Structures, and Providing Etiologic Insight. Mov. Disord. 2019, 34, $1851-1863$. [CrossRef]

171. Ryu, H.S.; Park, K.W.; Choi, N.; Kim, J.; Park, Y.M.; Jo, S.; Kim, M.J.; Kim, Y.J.; Kim, K.; Koh, S.B.; et al. Genomic Analysis Identifies New Loci Associated With Motor Complications in Parkinson's Disease. Front. Neurol. 2020, 11, 570. [CrossRef]

172. Cha, P.C.; Satake, W.; Ando-Kanagawa, Y.; Yamamoto, K.; Murata, M.; Toda, T. Genome-wide association study identifies zonisamide responsive gene in Parkinson's disease patients. J. Hum. Genet. 2020, 65, 693-704. [CrossRef]

173. Tan, M.M.X.; Lawton, M.A.; Jabbari, E.; Reynolds, R.H.; Iwaki, H.; Blauwendraat, C.; Kanavou, S.; Pollard, M.I.; Hubbard, L.; Malek, N.; et al. Genome-Wide Association Studies of Cognitive and Motor Progression in Parkinson's Disease. Mov. Disord. 2020. [CrossRef]

174. Toffoli, M.; Vieira, S.R.L.; Schapira, A.H.V. Genetic causes of PD: A pathway to disease modification. Neuropharmacology 2020, 170, 108022. [CrossRef]

175. Mullin, S.; Smith, L.; Lee, K.; D’Souza, G.; Woodgate, P.; Elflein, J.; Hällqvist, J.; Toffoli, M.; Streeter, A.; Hosking, J.; et al. Ambroxol for the Treatment of Patients With Parkinson Disease With and Without Glucocerebrosidase Gene Mutations: A Nonrandomized, Noncontrolled Trial. JAMA Neurol. 2020, 77, 427-434. [CrossRef]

176. Silveira, C.R.A.; MacKinley, J.; Coleman, K.; Li, Z.; Finger, E.; Bartha, R.; Morrow, S.A.; Wells, J.; Borrie, M.; Tirona, R.G.; et al. Ambroxol as a novel disease-modifying treatment for Parkinson's disease dementia: Protocol for a single-centre, randomized, double-blind, placebo-controlled trial. BMC Neurol. 2019, 19, 20. [CrossRef]

177. Sardi, S.P.; Viel, C.; Clarke, J.; Treleaven, C.M.; Richards, A.M.; Park, H.; Olszewski, M.A.; Dodge, J.C.; Marshall, J.; Makino, E.; et al. Glucosylceramide synthase inhibition alleviates aberrations in synucleinopathy models. Proc. Natl. Acad. Sci. USA 2017, 114, 2699-2704. [CrossRef] 
178. Sanofi. PRESS RELEASES. 5 February 2021. Available online: https://www.sanofi.com/en/media-room/press-releases/2021/2 021-02-05-07-30-00 (accessed on 26 June 2021).

179. Sheehan, P.; Heckman, L.D.; Fenn, T.; Wong, L.C.; Nelson, S.; Garimalla, S.; Haller, J.; Daily, J.; Politi, J.; Dai, Y.; et al. PR001 gene therapy improved phenotypes in models of Parkinson's disease with GBA1 mutation. Alzheimer's Dement. 2020, 16. [CrossRef]

180. Jeon, J.Y.; Sparreboom, A.; Baker, S.D. Kinase Inhibitors: The Reality Behind the Success. Clin. Pharm. 2017, 102, 726-730. [CrossRef]

181. Jennings, D.; Wetering de Rooij, J.; Vissers, M.; Heuberger, J.; Groeneveld, G.; Maciuca, R.; Kay, A.; Borin, M.; Wong, B.; Daryani, V.; et al. P54: LRRK2 Inhibition by BIIB122 / DNL151 in Double-Blind, Placebo-Controlled Phase 1 Healthy Volunteer and Phase 1B. In Proceedings of the XXVI World Congress on Parkinson's Disease and Related Disorders, Prague, Czech Republic, 1-4 May 2021.

182. Zhao, H.T.; John, N.; Delic, V.; Ikeda-Lee, K.; Kim, A.; Weihofen, A.; Swayze, E.E.; Kordasiewicz, H.B.; West, A.B.; Volpicelli-Daley, L.A. LRRK2 Antisense Oligonucleotides Ameliorate $\alpha$-Synuclein Inclusion Formation in a Parkinson's Disease Mouse Model. Mol. Nucleic Acids 2017, 8, 508-519. [CrossRef]

183. Volc, D.; Poewe, W.; Kutzelnigg, A.; Lührs, P.; Thun-Hohenstein, C.; Schneeberger, A.; Galabova, G.; Majbour, N.; Vaikath, N.; El-Agnaf, O.; et al. Safety and immunogenicity of the $\alpha$-synuclein active immunotherapeutic PD01A in patients with Parkinson's disease: A randomised, single-blinded, phase 1 trial. Lancet Neurol. 2020, 19, 591-600. [CrossRef]

184. Simuni, T.; Fiske, B.; Merchant, K.; Coffey, C.S.; Klingner, E.; Caspell-Garcia, C.; Lafontant, D.E.; Matthews, H.; Wyse, R.K.; Brundin, P.; et al. Efficacy of Nilotinib in Patients With Moderately Advanced Parkinson Disease: A Randomized Clinical Trial. JAMA Neurol. 2020. [CrossRef]

185. Payne, T.; Sassani, M.; Buckley, E.; Moll, S.; Anton, A.; Appleby, M.; Maru, S.; Taylor, R.; McNeill, A.; Hoggard, N.; et al. Ursodeoxycholic acid as a novel disease-modifying treatment for Parkinson's disease: Protocol for a two-centre, randomised, double-blind, placebo-controlled trial, The 'UP' study. BMJ Open 2020, 10, e038911. [CrossRef] [PubMed]

186. De Franco, E.; Flanagan, S.E.; Houghton, J.A.; Lango Allen, H.; Mackay, D.J.; Temple, I.K.; Ellard, S.; Hattersley, A.T. The effect of early, comprehensive genomic testing on clinical care in neonatal diabetes: An international cohort study. Lancet 2015, 386, 957-963. [CrossRef]

187. Bowman, P.; Sulen, Å.; Barbetti, F.; Beltrand, J.; Svalastoga, P.; Codner, E.; Tessmann, E.H.; Juliusson, P.B.; Skrivarhaug, T.; Pearson, E.R.; et al. Effectiveness and safety of long-term treatment with sulfonylureas in patients with neonatal diabetes due to KCNJ11 mutations: An international cohort study. Lancet Diabetes Endocrinol. 2018, 6, 637-646. [CrossRef]

188. Bowman, P.; Mathews, F.; Barbetti, F.; Shepherd, M.H.; Sanchez, J.; Piccini, B.; Beltrand, J.; Letourneau-Freiberg, L.R.; Polak, M.; Greeley, S.A.W.; et al. Long-term Follow-up of Glycemic and Neurological Outcomes in an International Series of Patients with Sulfonylurea-Treated. Diabetes Care 2021, 44, 35-42. [CrossRef]

189. Bacon, S.; Kyithar, M.P.; Rizvi, S.R.; Donnelly, E.; McCarthy, A.; Burke, M.; Colclough, K.; Ellard, S.; Byrne, M.M. Successful maintenance on sulphonylurea therapy and low diabetes complication rates in a HNF1A-MODY cohort. Diabet. Med. 2016, 33, 976-984. [CrossRef]

190. Shepherd, M.; Shields, B.; Ellard, S.; Rubio-Cabezas, O.; Hattersley, A.T. A genetic diagnosis of HNF1A diabetes alters treatment and improves glycaemic control in the majority of insulin-treated patients. Diabet. Med. 2009, 26, 437-441. [CrossRef]

191. Stride, A.; Shields, B.; Gill-Carey, O.; Chakera, A.J.; Colclough, K.; Ellard, S.; Hattersley, A.T. Cross-sectional and longitudinal studies suggest pharmacological treatment used in patients with glucokinase mutations does not alter glycaemia. Diabetologia 2014, 57, 54-56. [CrossRef]

192. Lynam, A.; McDonald, T.; Hill, A.; Dennis, J.; Oram, R.; Pearson, E.; Weedon, M.; Hattersley, A.; Owen, K.; Shields, B.; et al. Development and validation of multivariable clinical diagnostic models to identify type 1 diabetes requiring rapid insulin therapy in adults aged 18-50 years. BMJ Open 2019, 9, e031586. [CrossRef]

193. Redenšek, S.; Dolžan, V. The role of pharmacogenomics in the personalization of Parkinson's disease treatment. Pharmacogenomics 2020, 21, 1033-1043. [CrossRef] [PubMed]

194. Contin, M.; Martinelli, P.; Mochi, M.; Riva, R.; Albani, F.; Baruzzi, A. Genetic polymorphism of catechol-O-methyltransferase and levodopa pharmacokinetic-pharmacodynamic pattern in patients with Parkinson's disease. Mov. Disord. 2005, 20, 734-739. [CrossRef]

195. Corvol, J.C.; Bonnet, C.; Charbonnier-Beaupel, F.; Bonnet, A.M.; Fiévet, M.H.; Bellanger, A.; Roze, E.; Meliksetyan, G.; Ben Djebara, M.; Hartmann, A.; et al. The COMT Val158Met polymorphism affects the response to entacapone in Parkinson's disease: A randomized crossover clinical trial. Ann. Neurol. 2011, 69, 111-118. [CrossRef]

196. Kraemmer, J.; Smith, K.; Weintraub, D.; Guillemot, V.; Nalls, M.A.; Cormier-Dequaire, F.; Moszer, I.; Brice, A.; Singleton, A.B.; Corvol, J.C. Clinical-genetic model predicts incident impulse control disorders in Parkinson's disease. J. Neurol. Neurosurg. Psychiatry 2016, 87, 1106-1111. [CrossRef]

197. Redenšek, S.; Jenko Bizjan, B.; Trošt, M.; Dolžan, V. Clinical-Pharmacogenetic Predictive Models for Time to Occurrence of Levodopa Related Motor Complications in Parkinson's Disease. Front. Genet. 2019, 10, 461. [CrossRef]

198. Over, L.; Brüggemann, N.; Lohmann, K. Therapies for Genetic Forms of Parkinson's Disease: Systematic Literature Review. J. Neuromuscul. Dis. 2021. [CrossRef] 
199. Lythe, V.; Athauda, D.; Foley, J.; Mencacci, N.E.; Jahanshahi, M.; Cipolotti, L.; Hyam, J.; Zrinzo, L.; Hariz, M.; Hardy, J.; et al. GBA-Associated Parkinson's Disease: Progression in a Deep Brain Stimulation Cohort. J. Parkinsons Dis. 2017, 7, 635-644. [CrossRef]

200. ClinicalTrials.gov. Parkinson Disease and DBS: Cognitive Effects in GBA Mutation Carriers. Available online: https://www. clinicaltrials.gov / ct2/show / NCT03234478 (accessed on 26 June 2021).

201. ClinicalTrials.gov Identifier: NCT03234478. Available online: https:/ / clinicaltrials.gov/ct2/show/NCT03234478 (accessed on 26 June 2021).

202. Paul, K.C.; Schulz, J.; Bronstein, J.M.; Lill, C.M.; Ritz, B.R. Association of Polygenic Risk Score With Cognitive Decline and Motor Progression in Parkinson Disease. JAMA Neurol. 2018, 75, 360-366. [CrossRef]

203. Latourelle, J.C.; Beste, M.T.; Hadzi, T.C.; Miller, R.E.; Oppenheim, J.N.; Valko, M.P.; Wuest, D.M.; Church, B.W.; Khalil, I.G.; Hayete, B.; et al. Large-scale identification of clinical and genetic predictors of motor progression in patients with newly diagnosed Parkinson's disease: A longitudinal cohort study and validation. Lancet Neurol. 2017, 16, 908-916. [CrossRef]

204. Leonard, H.; Blauwendraat, C.; Krohn, L.; Faghri, F.; Iwaki, H.; Ferguson, G.; Day-Williams, A.G.; Stone, D.J.; Singleton, A.B.; Nalls, M.A.; et al. Genetic variability and potential effects on clinical trial outcomes: Perspectives in Parkinson's disease. J. Med. Genet. 2020, 57, 331-338. [CrossRef]

205. Lai, D.; Alipanahi, B.; Fontanillas, P.; Schwantes-An, T.-H.; Aasly, J.; Alcalay, R.N.; Beecham, G.W.; Berg, D.; Bressman, S.; Brice, A.; et al. Genome-wide association studies of LRRK2 modifiers of Parkinson's disease. medRxiv 2020. [CrossRef]

206. Liu, G.; Boot, B.; Locascio, J.J.; Jansen, I.E.; Winder-Rhodes, S.; Eberly, S.; Elbaz, A.; Brice, A.; Ravina, B.; van Hilten, J.J.; et al. Specifically neuropathic Gaucher's mutations accelerate cognitive decline in Parkinson's. Ann. Neurol. 2016, 80, 674-685. [CrossRef] [PubMed]

207. Mahlknecht, P.; Gasperi, A.; Willeit, P.; Kiechl, S.; Stockner, H.; Willeit, J.; Rungger, G.; Sawires, M.; Nocker, M.; Rastner, V.; et al. Prodromal Parkinson's disease as defined per MDS research criteria in the general elderly community. Mov. Disord. 2016, 31, 1405-1408. [CrossRef] [PubMed]

208. Postuma, R.B.; Gagnon, J.F.; Bertrand, J.A.; Génier Marchand, D.; Montplaisir, J.Y. Parkinson risk in idiopathic REM sleep behavior disorder: Preparing for neuroprotective trials. Neurology 2015, 84, 1104-1113. [CrossRef] [PubMed]

209. Mullin, S.; Beavan, M.; Bestwick, J.; McNeill, A.; Proukakis, C.; Cox, T.; Hughes, D.; Mehta, A.; Zetterberg, H.; Schapira, A.H.V. Evolution and clustering of prodromal parkinsonian features in GBA1 carriers. Mov. Disord. 2019, 34, 1365-1373. [CrossRef]

210. Mirelman, A.; Saunders-Pullman, R.; Alcalay, R.N.; Shustak, S.; Thaler, A.; Gurevich, T.; Raymond, D.; Mejia-Santana, H.; Orbe Reilly, M.; Ozelius, L.; et al. Application of the Movement Disorder Society prodromal criteria in healthy G2019S-LRRK2 carriers. Mov. Disord. 2018, 33, 966-973. [CrossRef]

211. Noyce, A.J.; R’Bibo, L.; Peress, L.; Bestwick, J.P.; Adams-Carr, K.L.; Mencacci, N.E.; Hawkes, C.H.; Masters, J.M.; Wood, N.; Hardy, J.; et al. PREDICT-PD: An online approach to prospectively identify risk indicators of Parkinson's disease. Mov. Disord. 2017, 32, 219-226. [CrossRef]

212. Griffanti, L.; Klein, J.C.; Szewczyk-Krolikowski, K.; Menke, R.A.L.; Rolinski, M.; Barber, T.R.; Lawton, M.; Evetts, S.G.; Begeti, F.; Crabbe, M.; et al. Cohort profile: The Oxford Parkinson's Disease Centre Discovery Cohort MRI substudy (OPDC-MRI). BMJ Open 2020, 10, e034110. [CrossRef]

213. Jennings, D.; Siderowf, A.; Stern, M.; Seibyl, J.; Eberly, S.; Oakes, D.; Marek, K.; Investigators, P. Conversion to Parkinson Disease in the PARS Hyposmic and Dopamine Transporter-Deficit Prodromal Cohort. JAMA Neurol. 2017, 74, 933-940. [CrossRef]

214. Krohn, L.; Ruskey, J.A.; Rudakou, U.; Leveille, E.; Asayesh, F.; Hu, M.T.M.; Arnulf, I.; Dauvilliers, Y.; Högl, B.; Stefani, A.; et al. Variants in REM sleep behavior disorder: A multicenter study. Neurology 2020, 95, e1008-e1016. [CrossRef]

215. Artzi, M.; Even-Sapir, E.; Lerman Shacham, H.; Thaler, A.; Urterger, A.O.; Bressman, S.; Marder, K.; Hendler, T.; Giladi, N.; Ben Bashat, D.; et al. DaT-SPECT assessment depicts dopamine depletion among asymptomatic G2019S LRRK2 mutation carriers. PLoS ONE 2017, 12, e0175424. [CrossRef]

216. Salat, D.; Noyce, A.J.; Schrag, A.; Tolosa, E. Challenges of modifying disease progression in prediagnostic Parkinson's disease. Lancet Neurol. 2016, 15, 637-648. [CrossRef]

217. Tolosa, E.; Vila, M.; Klein, C.; Rascol, O. LRRK2 in Parkinson disease: Challenges of clinical trials. Nat. Rev. Neurol. 2020, 16, 97-107. [CrossRef]

218. Klein, C.; Hattori, N.; Marras, C. MDSGene: Closing Data Gaps in Genotype-Phenotype Correlations of Monogenic Parkinson's Disease. J. Parkinsons Dis. 2018, 8, S25-S30. [CrossRef]

219. Grenn, F.P.; Kim, J.J.; Makarious, M.B.; Iwaki, H.; Illarionova, A.; Brolin, K.; Kluss, J.H.; Schumacher-Schuh, A.F.; Leonard, H.; Faghri, F.; et al. The Parkinson's Disease Genome-Wide Association Study Locus Browser. Mov. Disord. 2020, 35, $2056-2067$. [CrossRef]

220. Program GPsG. GP2: The Global Parkinson's Genetics Program. Mov. Disord. 2021. [CrossRef]

221. Rapsodi. PD Frontline. Rapsodi Study. 2021. Available online: https:/ / pdfrontline.com/en (accessed on 26 June 2021).

222. Parkinson's Foundation. PD GENEration:Mapping the Future of Parkinson's Disease: Parkinson's Foundation. 2021. Available online: https: / / www.parkinson.org/PDGENEration (accessed on 26 June 2021). 